"This document is the Accepted Manuscript version of a Published Work that appeared in final form in Inorganic Chemistry, copyright (C2020 American Chemical Society after peer review and technical editing by the publisher. To access the final edited and published work see:

https://pubs.acs.org/doi/abs/10.1021/acs.inorgchem.0c01215

\title{
Synthesis, Electrochemical Characterization and Water Oxidation Chemistry of Ru Complexes Containing the 2,6- Pyridinedicarboxylato Ligand
}

Md Asmaul Hoque, ${ }^{1,2}$ Marcos Gil-Sepulcre, Jordi Benet-Buchholz, ${ }^{1}$ Antoni Llobet, ${ }^{1,3, *}$ Carolina

$$
\text { Gimbert-Suriñach }{ }^{1, *}
$$

${ }^{1}$ Institute of Chemical Research of Catalonia (ICIQ), Barcelona Institute of Science and

Technology (BIST), Av. Països Catalans 16, 43007 Tarragona, Spain

${ }^{2}$ Departament de Química Física i Inorgànica, Universitat Rovira i Virgili, Campus Sescelades, C/Marcel·lí Domingo, s/n, 43007 Tarragona, Spain

${ }^{3}$ Universitat Autònoma de Barcelona, Departament de Química, Cerdanyola del Vallès, 08193

Barcelona, Spain

*Corresponding authors: allobet@iciq.cat, cgimbert@iciq.cat 


\begin{abstract}
The tridentate meridional ligand pyridyl-2,6-dicarboxylato $\left(\mathrm{pdc}^{2-}\right)$ has been used to prepare complexes $\left.\left.\mathrm{Ru}\left(\mathrm{pdc}-\mathrm{k}^{3}-\mathrm{N}^{1} \mathrm{O}^{2}\right)(\mathrm{DMSO})_{2} \mathrm{Cl}\right] \quad\left(\mathbf{1}^{\prime \prime}\right), \quad \mathrm{Ru}\left(\mathrm{pdc}-\mathrm{k}^{3}-\mathrm{N}^{1} \mathrm{O}^{2}\right)(\mathrm{bpy})(\mathrm{DMSO})\right] \quad\left(2^{\prime \prime}\right)$ and $\left\{\left[\mathrm{Ru}^{\prime \prime \prime}\left(\mathrm{pdc}-\mathrm{k}^{3}-\mathrm{N}^{1} \mathrm{O}^{2}\right)(\mathrm{bpy})\right]_{2}(\mu-\mathrm{O})\right\}\left(5^{\prime \prime \prime \prime \prime \prime \prime)}\right)$ where bpy: 2,2'-bipyridine. All complexes have been fully characterized through spectroscopic, electrochemical and single crystal X-ray diffraction techniques. Compounds $\mathbf{1}^{\text {"I }}$ and $\mathbf{2}^{\prime \prime}$ show $\mathrm{S} \rightarrow \mathrm{O}$ linkage isomerization of the DMSO ligand upon oxidation from $\mathrm{Ru}^{\prime \prime}$ to $\mathrm{Ru}$ 'II and thermodynamic and kinetic data have been obtained from cyclic voltammetry experiments. Dimeric complex $5^{1 \mathrm{III}, \mathrm{III}}$ is a precursor of the monomeric complex $\left[R u^{\prime \prime}\left(p d c-k^{3}-N^{1} O^{2}\right)(b p y)\left(H_{2} \mathrm{O}\right)\right] \quad\left(4^{\prime \prime}\right)$ which is a water oxidation catalyst. The electrochemistry and catalytic activity of $4^{\prime \prime}$ has been ascertained for the first time and compared with related Ru-aquo complexes that are also active for the water oxidation reaction. It shows a TOF $\max =0.2 \mathrm{~s}^{-1}$ and overpotential of $240 \mathrm{mV}$ in $\mathrm{pH} 1$. The overpotential shown by $4^{\prime \prime}$ is one of the lowest reported in the literature and is associated to the role of the two carboxylato groups of the pdc ligand, providing high electron density to the ruthenium complex.
\end{abstract}

Keywords: Ruthenium, DMSO linkage isomerization, Oxo-bridge, Redox chemistry, Water oxidation 


\section{1-Introduction}

Homogeneous molecular water oxidation to dioxygen catalysis based on transition metal complexes such as $\mathrm{Ru}, \mathrm{Ir}, \mathrm{Mn}, \mathrm{Fe}$, $\mathrm{Co}$ or $\mathrm{Cu}$ is an active field of research for its important role in artificial photosynthesis schemes. . $^{1,2,3,4,5,6,7,8,9,10,11,12}$ The selection of ligands is key to fulfill the metal requirements at different oxidation states while providing the required electronic properties, flexibility, orientation and robustness during catalytic conditions. In the case of ruthenium, the use of FAME ligands (flexible, adaptable, multidentate and equatorial) has resulted in excellent results. FAME ligands are pyridine-based ligands with one or more carboxylate groups that are crucial for the formation of seven coordinated intermediates at high oxidation states and that may also be involved in secondary coordination effects that are beneficial to the water oxidation catalysis. ${ }^{13,14}$ The best examples are based on bipyridine or terpyridine scaffolds containing two carboxylate groups achieving maximum turnover frequencies (TOF ${ }_{\text {max }}$ ) in the range of $10^{2}$ to $10^{4} \mathrm{~s}^{-1}$ which exceed by 1-2 orders of magnitude that of the oxygen evolving complex in the natural Photosystem II. ${ }^{15,16,17}$ More recently, we have demonstrated that the meridional 2,6-pyridinedicarboxylato $\left(\mathrm{pdc}^{2-}\right)$ tridentate ligand can also provide the desired FAME ligand effect giving rise to a ruthenium water oxidation catalyst $\left[\mathrm{Ru}^{\mathrm{IV}}\left(\mathrm{pdc}-\mathrm{K}^{3}-\mathrm{N}^{1} \mathrm{O}^{2}\right)(\mathrm{bpy})_{2}(\mathrm{O})\right]$ where bpy is $2,2^{\prime}$-bipyridine, that shows rates amongst the record values. ${ }^{3}$

In the present work we report the synthesis, structural, spectroscopic and electrochemical characterization of ruthenium complexes containing the $\mathrm{pdc}^{2-}$ ligand; [Ru"(pdc- ${ }^{3}$ $\left.\mathrm{N}^{1} \mathrm{O}^{2}\right)\left(\right.$ bpy)(DMSO)], $2^{\prime \prime}$ and $\left\{\left[\mathrm{Ru}^{\prime \prime \prime}\left(\operatorname{pdc}-\mathrm{K}^{3}-\mathrm{N}^{1} \mathrm{O}^{2}\right)(\text { bpy) }]_{2}(\mu-\mathrm{O})\right\}, 5^{\prime \prime \prime \prime \prime \prime \prime}\right.$, (Scheme 1), which are derivatives of the water oxidation catalyst $\left[\mathrm{Ru} \mathrm{u}^{\prime \prime \prime}\left(\mathrm{pdc}-\mathrm{K}^{3}-\mathrm{N}^{1} \mathrm{O}^{2}\right)(\mathrm{bpy})\left(\mathrm{H}_{2} \mathrm{O}\right)\right]^{+}, 4^{\prime \prime \prime}$. The catalytic activity of $\mathbf{4}^{\prime \prime \prime}$ is studied and put in context of the best WOCs reported to date. 


\section{2-Experimental Section}

\section{Materials}

$\mathrm{RuCl}_{3} \cdot \mathrm{xH}_{2} \mathrm{O}$ was purchased from Alfa-Aesar. The precursor complex $\left[\mathrm{Ru}(\mathrm{DMSO})_{4} \mathrm{Cl}_{2}\right]$ and $\left[R u^{\prime \prime \prime}\left(p d c-\mathrm{K}^{3}-\mathrm{N}^{1} \mathrm{O}^{2}\right)(\mathrm{bpy}) \mathrm{Cl}\right]$ were prepared according to the literature procedures. ${ }^{15,18}$ The ligand precursor 2,6-pyridinedicarboxylic acid $\left(\mathrm{H}_{2} \mathrm{pdc}\right)$ and other reagents and chemicals were obtained from Aldrich and used as received. When required, solvents were dried by following the standard procedures, distilled under nitrogen and used immediately. High purity deionized water used for the electrochemistry experiments was obtained by passing distilled water through a nanopure Milli-Q water purification system. For other spectroscopic and electrochemical studies, HPLC-grade solvents were used.

\section{Instrumentation and Methods}

A Bruker Avance $500 \mathrm{MHz}$ was used to carry out NMR spectroscopy. ESI-Mass spectra were recorded using micromass Q-TOF mass spectrometer. Elemental analyses were carried out on Perkin-Elmer $240 \mathrm{C}$ elemental analyzer. The $\mathrm{pH}$ of the solutions was determined by a $\mathrm{pH}$ meter (CRISON, Basic 20+) calibrated before measurements through standard solutions at $\mathrm{pH} 2.00$, 4.01, 7.00, 9.21 and 11.0. All electrochemical experiments were performed with an IJ-Cambria CHI-660 potentiostat using a three-electrode cell for cyclic voltammetry (CV) and differential pulse voltammetry (DPV) or two compartment cell for bulk electrolysis. $E_{1 / 2}$ values reported in this work were estimated from CV experiments as the average of the oxidative and reductive peak potentials $\left(E_{p, \mathrm{a}}+E_{\mathrm{p}, c}\right) / 2$ or from DPV. The Reference Electrode (RE) was $\mathrm{Hg} / \mathrm{Hg}_{2} \mathrm{SO}_{4}\left(\mathrm{~K}_{2} \mathrm{SO}_{4}\right.$ saturated) unless indicated and potentials were converted to NHE by adding $0.65 \mathrm{~V} \cdot{ }^{19}$

Glassy carbon disk $\left(\phi=0.3 \mathrm{~cm}, \mathrm{~S}=0.07 \mathrm{~cm}^{2}\right)$, Pt disk and $\mathrm{Hg} / \mathrm{Hg}_{2} \mathrm{SO}_{4}\left(\mathrm{~K}_{2} \mathrm{SO}_{4}\right.$ saturated) were used as Working Electrode (WE), Counter Electrode (CE) and Reference Electrode (RE) respectively, unless explicitly mentioned. Glassy carbon electrodes were polished with 0.05 $\mu \mathrm{m}$ alumina $\left(\mathrm{Al}_{2} \mathrm{O}_{3}\right)$ and rinsed with water. $\mathrm{CVs}$ and DPVs were $i \mathrm{R}$ compensated by the potentiostat in all the measurements unless indicated. CVs were recorded at $100 \mathrm{mV} \cdot \mathrm{s}^{-1} \mathrm{scan}$ rate, unless explicitly expressed. The DPV parameters were $\Delta E=4 \mathrm{mV}$, Amplitude $=50 \mathrm{mV}$, Pulse width $=0.05 \mathrm{~s}$, Sampling width $=0.0167 \mathrm{~s}$, Pulse period $=0.5 \mathrm{~s}$. The complexes were dissolved in dichloromethane (DCM) containing the necessary amount of $\left[(n-\mathrm{Bu})_{4} \mathrm{~N}\right]\left[\mathrm{PF}_{6}\right]$ (TBAH) as supporting electrolyte to yield a $0.1 \mathrm{M}$ ionic strength $(I)$ solution. In aqueous solution the electrochemical experiments were carried out in $0.1 \mathrm{M}$ triflic acid solution for $\mathrm{pH}$ 
1, prepared by exact dilution of a pure triflic acid sample $(>99 \%)$ or in phosphate buffer solutions with $I=0.1 \mathrm{M}$ and desired $\mathrm{pH}$. The following buffers were used: sodium dihydrogen phosphate/phosphoric acid up to $\mathrm{pH}=4\left(\mathrm{p} K_{\mathrm{a}}=2.12\right)$, sodium hydrogen phosphate/ sodium dihydrogen phosphate up to $\mathrm{pH}=9\left(\mathrm{p} K_{\mathrm{a}}=7.67\right)$, sodium hydrogen phosphate/sodium phosphate up to $\mathrm{pH}=13\left(\mathrm{p} K_{\mathrm{a}}=12.12\right)$ and also $0.1 \mathrm{M} \mathrm{CF}_{3} \mathrm{SO}_{3} \mathrm{H}$ for $\mathrm{pH}=1.0$. For routine bulk electrolysis experiments, a Pt grid was used as a WE, another Pt grid as a $\mathrm{CE}$ and a $\mathrm{Hg} / \mathrm{Hg}_{2} \mathrm{SO}_{4}$ $\left(\mathrm{K}_{2} \mathrm{SO}_{4}\right.$ saturated) as a $\mathrm{RE}$.

Online manometric measurements were performed on a Testo 521 differential pressure manometer with an operating range of $0.1-10 \mathrm{kPa}$ and accuracy within $0.5 \%$ of the measurements. The manometer was coupled to thermostatic reaction vessels $\left(25^{\circ} \mathrm{C}\right)$ for dynamic monitoring of the headspace pressure above each reaction solution. The manometer's secondary ports were connected to thermostatic reaction vessels containing the same solvents and headspace volumes as the sample vials. Each measurement for a reaction solution $(2.0 \mathrm{~mL})$ was performed at $298 \mathrm{~K}$. The solution for the manometric measurements was prepared as follows: control potential electrolysis was carried out for 10 min with $1 \mathrm{mM}$ of complex $5^{\mathrm{III}, \mathrm{II}}$ in $\mathrm{pH} 1$ solution. It was assumed that upon breaking of dimeric complex $5^{111,11 \mathrm{I}}$, it produced 2 equivalent of monomeric complex $4^{\prime \prime}$, this results in a concentration of 4 " of $2 \mathrm{mM}$. This complex was diluted to half with additional $\mathrm{pH} 1$ solution to get $1 \mathrm{mM}$ of $4^{\prime \prime}$.

Synthesis of $\left[\mathrm{Et}_{3} \mathrm{NH}\right]\left[\mathrm{Ru}^{\prime \prime}\left(\right.\right.$ pdc- $\left.\left.\mathbf{R}^{3}-\mathrm{N}^{1} \mathrm{O}^{2}\right)(\mathrm{DMSO}){ }_{2} \mathrm{Cl}\right] \cdot \mathrm{H}_{2} \mathrm{O}, \mathbf{1}^{\prime \prime}$. In a $100 \mathrm{~mL}$ two neck round bottom flask, [Ru(DMSO) $\left.{ }_{4} \mathrm{Cl}_{2}\right](450 \mathrm{mg}, 0.93 \mathrm{mmol}), 2,6$-pyridine dicarboxylic acid (155 mg, $0.93 \mathrm{mmol}$ ) and triethylamine $(0.2 \mathrm{~mL})$ were dissolved in $30 \mathrm{~mL}$ of degassed methanol and were reflux for $5 \mathrm{~h}$ under $\mathrm{N}_{2}$ atmosphere. The resulting mixture was filtered and the volume was reduced to $5 \mathrm{~mL}$. Then $30 \mathrm{~mL}$ of diethyl ether was added to obtain an orange precipitate. The solid was filtered and washed with diethyl ether $(3 \times 20 \mathrm{~mL})$ and dried under vacuum. Yield: $460 \mathrm{mg}(0.82 \mathrm{mmol}, 88 \%)$. The characterization data matches with reported complex. ${ }^{20}$

Synthesis of [Ru"(pdc- $\left.\left.\mathbf{K}^{3}-\mathrm{N}^{1} \mathrm{O}^{2}\right)(\mathrm{bpy})(\mathrm{DMSO})\right] \cdot 1.5 \mathrm{H}_{2} \mathrm{O}, \mathbf{2}^{11}$. In a $100 \mathrm{~mL}$ two neck round bottom flask, [Et $\left.{ }_{3} \mathrm{NH}\right]\left[\mathrm{Ru}^{\prime \prime}\left(\mathrm{pdc}-\mathrm{K}^{3}-\mathrm{N}^{1} \mathrm{O}^{2}\right)(\mathrm{DMSO})_{2} \mathrm{Cl}\right], 1^{11}$ (560 mg, $1 \mathrm{mmol}$ ) and 2,2'-bipyridine (156 mg, $1 \mathrm{mmol}$ ) were dissolved in $40 \mathrm{~mL}$ degassed methanol solvent and refluxed for 4 hours under $\mathrm{N}_{2}$ atmosphere. The mixture was then evaporated to dryness and the resulting solid dissolved in $\mathrm{CH}_{2} \mathrm{Cl}_{2}$ and purified over neutral alumina using a mixture of $\mathrm{CH}_{2} \mathrm{Cl}_{2} / \mathrm{MeOH}(100: 2)$ as eluent. The first orange-red fraction was collected and identified as complex $\mathbf{2}^{\prime \prime}$. Yield: $60 \mathrm{mg}(0.12$ mmol, $12 \%)$. Anal. Calc. for $\left(\mathrm{C}_{19} \mathrm{H}_{17} \mathrm{~N}_{3} \mathrm{O}_{5} \mathrm{RuS} \cdot 1.5 \mathrm{H}_{2} \mathrm{O}\right)$ : C, 43.26\%; $\mathrm{H}, 3.82 \% ; \mathrm{N}, 7.94 \% ; \mathrm{S}, 6.08 \%$. Found: C, 43.35\%; H, 3.15\%; N, 7.85\%; S, 6.18\%. ${ }^{1} \mathrm{H}-\mathrm{NMR}\left(500 \mathrm{MHz},\left[\mathrm{d}_{2}\right]-\mathrm{DCM}\right) \delta: 10.61$ (d, J = 
$5.7 \mathrm{~Hz}, 1 \mathrm{H}), 8.29(\mathrm{~d}, J=8.4 \mathrm{~Hz}, 2 \mathrm{H}), 8.24(\mathrm{~d}, J=7.7 \mathrm{~Hz}, 2 \mathrm{H}), 8.14(\mathrm{t}, J=7.8 \mathrm{~Hz}, 1 \mathrm{H}), 7.89(\mathrm{tt}, J=$ 3.5 and $7.8 \mathrm{~Hz}, 2 \mathrm{H}), 7.61(\mathrm{t}, J=7.3 \mathrm{~Hz}, 1 \mathrm{H}), 7.29(\mathrm{t}, J=6.6 \mathrm{~Hz}, 1 \mathrm{H}), 6.96(\mathrm{~d}, J=5.6 \mathrm{~Hz}, 1 \mathrm{H}), 2.65$ (s, 6H). ${ }^{13}$ C-NMR (125 MHz, [d 2 ]-DCM) $\delta: 172.6,158.3,158.1,157.4,154.3,148.7,138.4,137.2$, 136.6, 128.9, 127.1, 123.5, 123.1, 51.2 and 42.6. $\left(\mathrm{ESI}{ }^{+}-\mathrm{HRMS} ; \mathrm{MeOH}\right) \mathrm{m} / \mathrm{z}$ : calc. for $[\mathrm{M}+\mathrm{Na}]^{+}$: 523.9857, found $\mathrm{m} / \mathrm{z}: 523.9830$.

Synthesis of $\left\{\left[\mathrm{Ru}^{\prime \prime \prime}\left(\mathbf{p d c}-\mathrm{K}^{3}-\mathrm{N}^{1} \mathrm{O}^{2}\right)(\mathbf{b p y})\right]_{2}(\mu-\mathrm{O})\right\} \cdot 2 \mathrm{H}_{2} \mathrm{O}, 5^{11, \prime \prime \prime \prime}$. In a $100 \mathrm{~mL}$ two neck round-bottom flask, [Ru"'(pdc- $\left.\left.\mathrm{K}^{3}-\mathrm{N}^{1} \mathrm{O}^{2}\right)(\mathrm{bpy}) \mathrm{Cl}\right]^{15}(100 \mathrm{mg}, 0.22 \mathrm{mmol})$ was dissolved in $40 \mathrm{~mL}$ of acetone/water (3:1) followed by addition of triethylamine $(0.20 \mathrm{~mL})$ and stirred for 5 minutes under $\mathrm{N}_{2}$. Then silver perchlorate $(120 \mathrm{mg}, 0.58 \mathrm{mmol})$ was added to the reaction mixture and stirred for 30 minutes at $50^{\circ} \mathrm{C}$. The precipitated $\mathrm{AgCl}$ was filtered through Celite ${ }^{\circledast}$. The mixture was then evaporated to dryness and the resulting solid was dissolved in $\mathrm{CH}_{2} \mathrm{Cl}_{2}$ and purified by chromatography with neutral alumina using a mixture of $\mathrm{CH}_{2} \mathrm{Cl}_{2} / \mathrm{MeOH}(100: 4)$ as eluent. The blue colour fraction was collected and evaporated to dryness to give complex $5^{111,111}$. Yield $37 \mathrm{mg}(0.043 \mathrm{mmol}, 20 \%)$. Anal. Calc. for $\left(\mathrm{C}_{34} \mathrm{H}_{22} \mathrm{~N}_{6} \mathrm{O}_{9} \mathrm{Ru}_{2} \cdot 2 \mathrm{H}_{2} \mathrm{O}\right): \mathrm{C}, 45.54 \% ; \mathrm{H}, 2.92 \% ; \mathrm{N}$, 9.37\%. Found: C, 45.31\%; H, 2.50\%; N, 9.26\%. ${ }^{1} \mathrm{H}-\mathrm{NMR}\left(500 \mathrm{MHz},\left[\mathrm{d}_{6}\right]\right.$-DMSO) $\delta: 8.75$ (d, $J=$ $8.1 \mathrm{~Hz}, 1 \mathrm{H}), 8.68(\mathrm{~d}, J=8.2 \mathrm{~Hz}, 1 \mathrm{H}), 8.07(\mathrm{dd}, J=7.6 \mathrm{~Hz}$ and $1.4 \mathrm{~Hz}, 1 \mathrm{H}), 7.98(\mathrm{t}, J=7.6 \mathrm{~Hz}, 1 \mathrm{H})$, $7.87(\mathrm{td}, J=8.95 \mathrm{~Hz}$ and $1.3 \mathrm{~Hz}, 1 \mathrm{H}), 7.72(\mathrm{t}, J=7.75 \mathrm{~Hz}, 1 \mathrm{H}), 7.33(\mathrm{t}, J=7.0 \mathrm{~Hz}, 1 \mathrm{H}), 7.29(\mathrm{t}, J$ $=7.15 \mathrm{~Hz}, 1 \mathrm{H}), 6.89(\mathrm{dd}, J=7.75 \mathrm{~Hz}$ and $1.4 \mathrm{~Hz}, 1 \mathrm{H}), 6.59(\mathrm{~d}, J=4.9 \mathrm{~Hz}, 1 \mathrm{H}), 6.54(\mathrm{~d}, J=5.3 \mathrm{~Hz}$, 1H). ${ }^{13}$ C-NMR (125 MHz, [d 6 -DMSO ) $\delta: 173.2,169.6,164.6,159.5,158.6,153.9,152.3,150.4$, 140.9, 140.1, 139.9, 127.4, 125.4, 125.3, 124.8, 123.5 and 123.3. (ESI+-HRMS; MeOH) m/z: calc. for $[\mathrm{M}+\mathrm{Na}]^{+}$: 884.9492, found $\mathrm{m} / \mathrm{z}$ : 884.9441.Single Crystal X-Ray Structure Determinations

Crystal Preparation: Crystals of $\left[\mathrm{Et}_{3} \mathrm{NH}\right]\left[\mathrm{Ru}^{\prime \prime}\left(p d c-\mathrm{R}^{3}-\mathrm{N}^{1} \mathrm{O}^{2}\right)(\mathrm{DMSO})_{2} \mathrm{Cl}\right], 1^{\prime \prime} \quad\left[\mathrm{Ru}^{\prime \prime}\left(p d c-\mathrm{R}^{3}-\right.\right.$

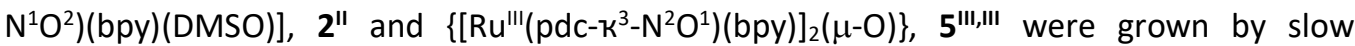
evaporation of 1:1 methanol:benzene, 1:1 methanol:diethylether and 1:1 dichloromethane:hexane respectively. The crystals used for structure determination were selected using a Zeiss stereomicroscope using polarized light and prepared under inert conditions immersed in perfluoropolyether as protecting oil for manipulation. Data Collection: Crystal structure determination for compounds $\mathbf{1}^{\mathrm{II}}, \mathbf{2}^{\mathrm{II}}$ and $\mathbf{5}^{\mathrm{III}, \mathrm{III}}$ were carried out using a Apex DUO Kappa 4-axis goniometer equipped with an APPEX 2 4K CCD area detector, a Microfocus Source E025 luS using MoK $_{\alpha}$ radiation, Quazar MX multilayer Optics as monochromator and an Oxford Cryosystems low temperature device Cryostream 700 plus ( $T$ $\left.=-173^{\circ} \mathrm{C}\right)$. Crystal structure determination for samples Full-sphere data collection was used 
with $\omega$ and $\varphi$ scans. Programs used: Data collection APEX-2, ${ }^{21}$ data reduction Bruker Saint $\mathrm{V} / 60 \mathrm{~A}^{22}$ and absorption correction SADABS. ${ }^{23}$ Structure Solution and Refinement: Crystal structure solution was achieved using the computer program SHELXT. ${ }^{24}$ Visualization was performed with the program SHELXIe. ${ }^{25}$ Missing atoms were subsequently located from difference Fourier synthesis and added to the atom list. Least-squares refinement on $F^{2}$ using all measured intensities was carried out using the program SHELXL $2015 .{ }^{26}$ All non-hydrogen atoms were refined including anisotropic displacement parameters. Comments to the Structures: $\left[\mathrm{Et}_{3} \mathrm{NH}\right]\left[\mathrm{Ru}^{\prime \prime}\left(\mathrm{pdc}-\mathrm{K}^{3}-\mathrm{N}^{1} \mathrm{O}^{2}\right)(\mathrm{DMSO})_{2} \mathrm{Cl}\right], 1^{\prime \prime}$ : The asymmetric unit contains two molecules of the metal complex (each coordinated to two DMSO molecules), two triethylammonium cations, two water molecules and two benzene molecules. The benzene molecules are disordered in two orientations. [Ru"(pdc- $\left.\left.\mathrm{r}^{3}-\mathrm{N}^{2} \mathrm{O}^{1}\right)(\mathrm{bpy})(\mathrm{DMSO})\right], \mathbf{2}^{\prime \prime}$ : The asymmetric unit contains one molecule of the metal complex (coordinated to a DMSO molecule) and two molecules of water. $\left\{\left[\mathrm{Ru}^{\prime \prime \prime}\left(\mathrm{pdc}-\mathrm{K}^{3}-\mathrm{N}^{2} \mathrm{O}^{1}\right)(\mathrm{bpy})\right]_{2}(\mu-\mathrm{O})\right\}, 5^{\mathrm{II \prime \prime}, \mathrm{II}}$ : The asymmetric unit contains two independent molecules of the metal complex and 5.1 molecules of dichloromethane. The dichloromethane molecules are disordered in 11 positions with a ratio: 1.00:0.75:0.60:0.40:0.55:0.45:0.70:0.20:0.25:0.10:0.10. 


\section{3-Results and Discussion}

\section{1-Synthesis and Characterization of Complexes 1-5}

The reaction of 2,6-pyridinedicarboxylic acid $\left(\mathrm{H}_{2} \mathrm{pdc}\right)$ with the ruthenium precursor complex $\left[\mathrm{Ru}(\mathrm{DMSO}){ }_{4} \mathrm{Cl}_{2}\right]$ in the presence of $\mathrm{Et}_{3} \mathrm{~N}$ as a base in $\mathrm{MeOH}$ under reflux gives complex $\mathbf{1}^{11}$, which upon treatment with 1 equivalent of bpy gives complex 2" (Scheme 1, top) together with the side-product $\left[\mathrm{Ru}\right.$ " $\left(\right.$ pdc- $\left.\left.\mathrm{K}^{2}-\mathrm{N}^{1} \mathrm{O}^{1}\right)(\mathrm{bpy})_{2}\right]$, recently reported. ${ }^{3}$

On the other hand, when $\mathrm{RuCl}_{3}$ is used as ruthenium source, the analogous complex [Ru"'(pdc$\left.\left.\mathrm{K}^{3}-\mathrm{N}^{1} \mathrm{O}^{2}\right)(\mathrm{bpy}) \mathrm{Cl}\right], 3^{\text {III }}$ with a chlorido ligand instead of DMSO ligand is obtained as we recently reported. ${ }^{3}$ The addition of $\mathrm{AgClO}_{4}$ to a solution of $3^{\text {"II' }}$ generates an unstable species identified

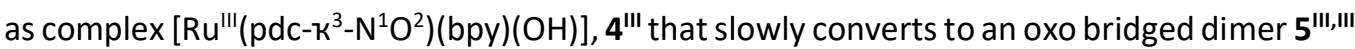
and other unidentified insoluble species (Scheme 1, bottom). Complex $5^{111,111}$ was purified by column chromatography and isolated as a blue solid in $20 \%$ yield.

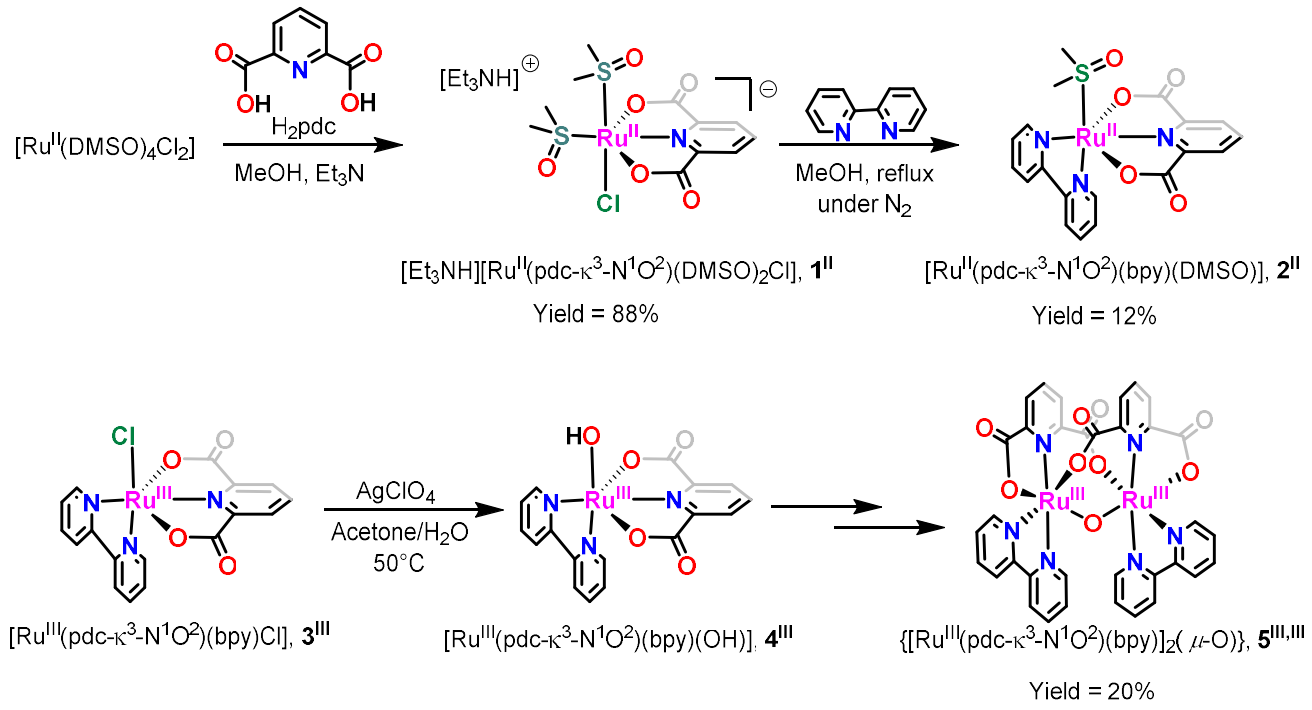

Scheme 1. Synthetic strategy and labelling scheme used for the ligands and complexes described in this work.

Complexes $\mathbf{1}^{11}, \mathbf{2}^{\mathrm{II}}$ and $\mathbf{5}^{\mathrm{III}, \mathrm{III}}$ were structurally characterized in the solid state by single crystal X-ray diffraction (XRD) analysis and in solution by NMR spectroscopy. While the XRD structure of $\mathbf{1}^{11}$ is known, ${ }^{20}$ complexes $2^{11}$ and $5^{111,111}$ have never been reported before and are characterized here for the first time. The ORTEP plots of complex $\mathbf{2}^{\prime \prime}$ in Figure 1a displays highly distorted octahedral geometry around the ruthenium metal due to the strain imposed by the $\mathrm{pdc}^{2-}$ meridional ligand with O-Ru-O angle of $158.1(5)^{\circ}$ as opposed to the $180^{\circ}$ expected for 
an ideal octahedron. Bond distances and angles are very similar to those of $\mathbf{3}^{\mathrm{III}}$ and other related complexes reported in the literature. $3,20,27,28$ The bpy ligand occupies both axial and equatorial positions assuming the $\mathrm{k}-\mathrm{N}^{1} \mathrm{O}^{2}-\mathrm{pdc}^{2-}$ ligand binds in the equatorial plane.

The crystal structure of dimeric complex $5^{\mathrm{III}, \mathrm{III}}$ shows that both metal centers exhibit a distorted octahedral geometry (Figure $1 \mathrm{~b}$ ). The Ru- $\mathrm{O}_{\text {oxo }}$ bond distances are 1.869 (4) $\AA$ and 1.885 (4) $\AA$, which are in the range of reported Ru'"-O-Ru'l' type of complexes..$^{29,30,31,32}$

a)

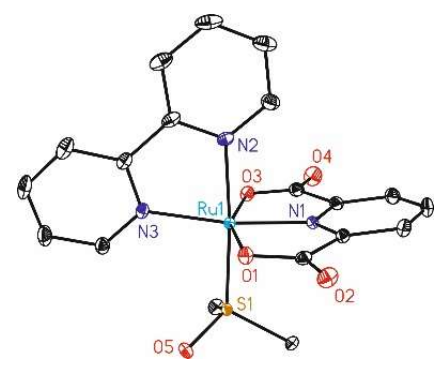

b)

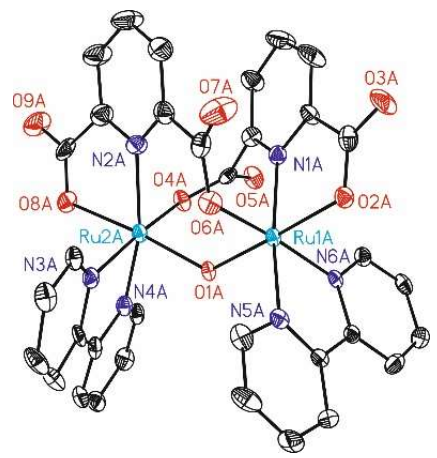

Figure 1. ORTEP plots at $50 \%$ probability for a) [Ru" $\left(\right.$ pdc- $\left.\left.\mathrm{K}^{3}-\mathrm{N}^{1} \mathrm{O}^{2}\right)(\mathrm{bpy})(\mathrm{DMSO})\right], \mathbf{2}^{\prime \prime}$ and b) $\{[\mathrm{Ru}$ "'"(pdc$\left.\left.\mathrm{K}^{3}-\mathrm{N}^{1} \mathrm{O}^{2}\right)(\text { (bpy) }]_{2}(\mu-\mathrm{O})\right\}, 5^{111,111}$.

The angle defined by Ru-O-Ru in complex $5^{111, I I I}$ is significantly bent with a value of $125.9(2)^{\circ}$. As reported before, this angle has a strong influence in the electronic configuration of the molecule, which will be affected by the overlapping of the orbitals of the oxo ligand with those of the ruthenium centers (see molecular orbital scheme in Figure 2, where the Ru-O bond is taken as $\mathrm{z}$ axis). For bent structures such as in $5^{\mathrm{III}, \mathrm{III}}$ a high-energy gap between $\pi_{1}{ }^{*}$ and $\pi_{2}{ }^{*}$ orbitals is expected resulting in the following diamagnetic electronic configuration; $\left(\pi_{1}^{b}\right)^{2}$ $\left(\pi_{2}{ }^{\mathrm{b}}\right)^{2}\left(\pi_{1}{ }^{\mathrm{nb}}\right)^{2}\left(\pi_{2}{ }^{\mathrm{nb}}\right)^{2}\left(\pi_{1}{ }^{*}\right)^{2}\left(\pi_{2}{ }^{*}\right)^{0} .{ }^{29}$ In contrast, dinuclear oxo-bridged Ru $u^{\text {III }}$ complexes with RuO-Ru angles close to $180^{\circ}$ display a paramagnetic behavior because their $\pi_{1}{ }^{*}$ and $\pi_{2}{ }^{*}$ orbitals are either degenerate or very close in energy.$^{29}$ The diamagnetic and symmetric nature of $5^{111,111}$ is clear from its ${ }^{1} \mathrm{H}$ NMR spectrum in $\left[\mathrm{d}_{6}\right]$-DMSO solution, which shows two single set of resonances for the $\mathrm{pdc}^{2-}$ and the bpy ligands, respectively (Figure 2).

Although bidimensional NMR experiments allowed us to unequivocally assign all the resonances to the respective ligands, it was not possible to distinguish between the two pyridine rings of the bpy ligand, which have been arbitrary labeled as a diamond $(\bullet)$ and square ( $\square$ ) symbols in the ${ }^{1} \mathrm{H}$ NMR spectrum in Figure 2 (see also Figure S4-S6). 
The ${ }^{1} \mathrm{H}$ NMR spectrum of complex $2^{11}$ in $\left[\mathrm{d}_{2}\right]$-DCM shows a characteristic signal at low field $(\delta$ $=10.61 \mathrm{ppm})$ for a proton deshielded by the through space interaction with the closest DMSO ligand (Figure S1-S3). ${ }^{33}$ Protons of the two methyl groups of the DMSO ligand are clearly visible at high field $(\delta=2.65 \mathrm{ppm})$ as expected.

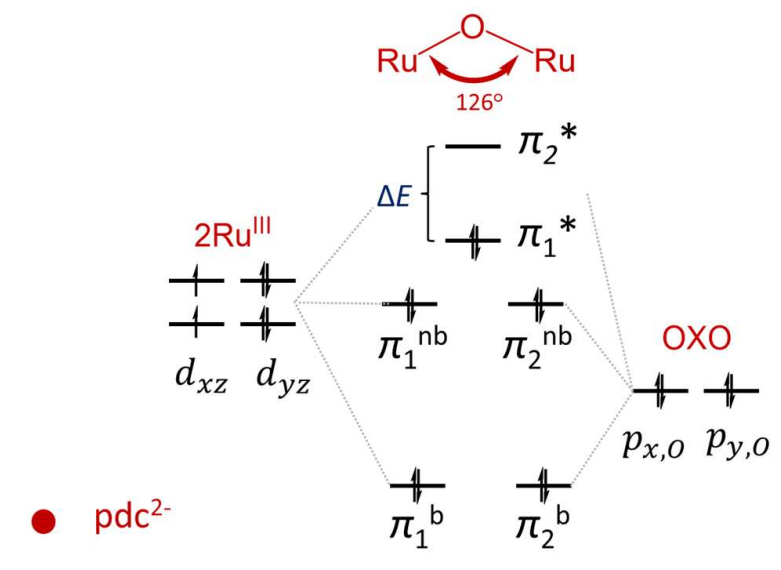

$\boldsymbol{\nabla}$ bpy

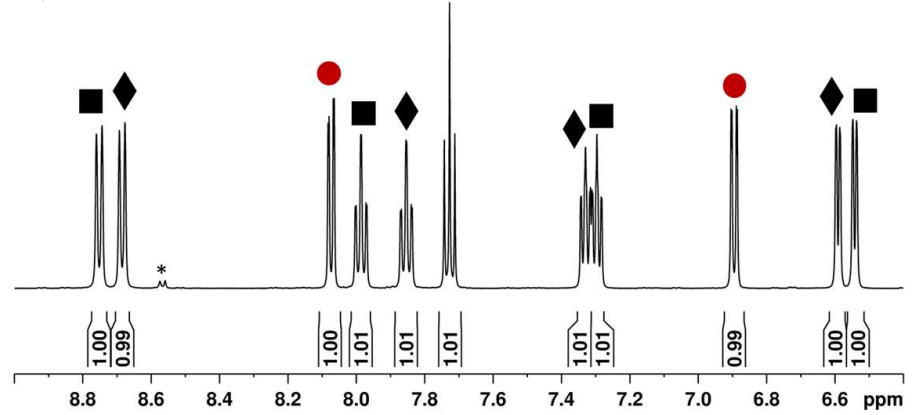

Figure 2. ${ }^{1} \mathrm{H}$ NMR spectrum of complex $\left\{\left[R u^{\prime \prime \prime}\left(p d c-\mathrm{k}^{3}-\mathrm{N}^{1} \mathrm{O}^{2}\right)(\mathrm{bpy})\right]_{2}(\mu-\mathrm{O})\right\}, 5^{\mathrm{II \prime}, \mathrm{II}}$ in $\left[\mathrm{d}_{6}\right]-\mathrm{DMSO}(500$ $\mathrm{MHz}, 298 \mathrm{~K})$. Squares and diamonds indicate the signals of the two independent pyridine rings in the bipyridine ligand. Asterisks indicate unidentified signal.

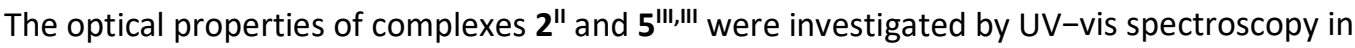
DCM (Figure 3). Both compounds show $\pi-\pi^{*}$ transitions due to the aromatic ligands below $350 \mathrm{~nm}$ and weaker metal to ligand charge transfer (MLCT) $d-\pi^{*}$ bands showing between 350

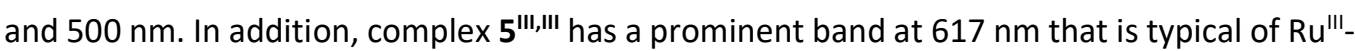
O-Ru'l type of complexes. ${ }^{29,32}$ 


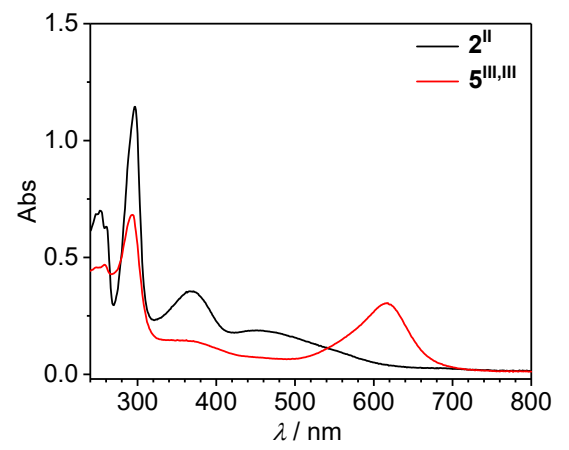

Figure 3. UV-vis spectra of $0.2 \mathrm{mM}$ of complexes $\mathbf{2}^{\mathrm{II}}$ (black) and $\mathbf{5}^{\mathrm{III}, \mathrm{III}}$ (red) in DCM.

\section{3-2-Electrochemistry in Organic Solvent}

The redox properties of complexes 1, $\mathbf{2}$ and $\mathbf{5}$ were analysed by means of cyclic voltammetry

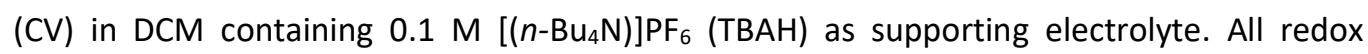
potentials reported in this work are referred to the NHE electrode.

\section{DMSO Linkage Isomerization of Complexes $1^{\prime \prime}$ and $2^{\prime \prime}$}

Complexes $\mathbf{1}^{\text {"I }}$ and $\mathbf{2}^{\text {"I }}$ are two new examples of complexes that show $\mathrm{S} \rightarrow 0$ DMSO linkage isomerization by changing oxidation state of the Ru metal center from II to III (Scheme 2). As shown in Figure 4 and Figure 58 complex $1^{11}$ shows an irreversible wave with $E_{\mathrm{p}, \mathrm{a}}^{1}=1.05 \mathrm{~V}$ and $E_{\mathrm{p}, \mathrm{c}}^{1}=0.87 \mathrm{~V}$ associated with the $\mathrm{Ru^{II/I }}{ }^{\mathrm{II}}-\mathrm{S}$ redox couple. After the anodic scan a new wave appears at $E_{\mathrm{p}, \mathrm{c}}^{2}=0.19 \mathrm{~V}$ and $E_{\mathrm{p}, \mathrm{a}}^{2}=0.32 \mathrm{~V}$ assigned to the $\mathrm{Ru} \mathrm{u}^{\mathrm{II} / \mathrm{I}}-\mathrm{O}$ couple. This significant anodic shift in potential due to the distinct coordination mode of the DMSO ligand has been observed before and is attributed to the lower $\pi$-accepting properties of the O-bonded ligand as compared to the S-bonded DMSO ligand. ${ }^{33}$ The peak intensity ratios $\left[i_{p, c}\right] /\left[i_{p, a}\right]$ depend strongly on the scan rate for both redox couples as a result of the different kinetics of the isomerization processes described in Scheme 2 . In addition, the relative intensity of the two redox couples change significantly after holing the potential for two minutes at $-0.2 \mathrm{~V}$ or at $1.4 \mathrm{~V}$ before scanning the CV (Figure 4 and Figure S8).

The equilibrium constants $K^{\prime \prime \prime}{ }_{\mathrm{s}} \rightarrow 0, K^{\prime \prime}{ }_{\mathrm{O} \rightarrow \mathrm{s}}$ in Scheme 2 as well as the respective kinetic constants can be calculated following a mathematical treatment that uses the peak intensities of the cyclic voltammetry at different scan rates in the presence and in the absence of the isomerization process (see supporting information)..$^{34}$ These calculations result in equilibrium constants of $\mathrm{K}^{\prime \prime \prime} \mathrm{O} \rightarrow \mathrm{S}=0.60$ and $\mathrm{K}_{\mathrm{O} \rightarrow \mathrm{S}}=5.9 \times 10^{11}$ and kinetic constants of $\mathrm{K}^{\prime \prime \prime} \mathrm{s} \rightarrow 0=9.2 \times 10^{-1} \mathrm{~s}$ ${ }^{1}$ and $k^{\prime \prime} \rightarrow \mathrm{S}=9.4 \times 10^{-2} \mathrm{~s}^{-1}$ 


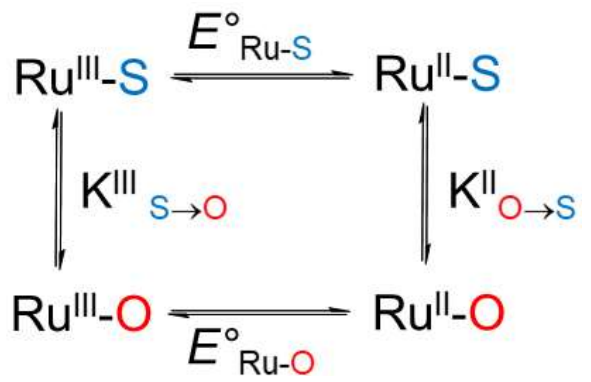

Scheme 2. Square mechanism associated with the $S \rightarrow O$ DMSO linkage isomerization by changing oxidation state of the Ru metal center.
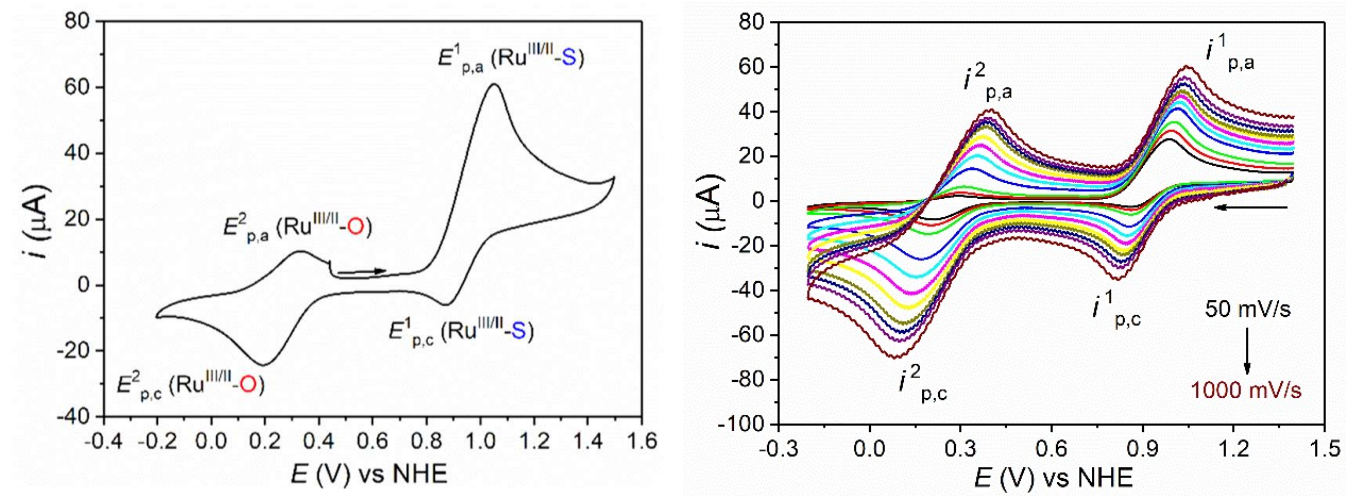

Figure 4. CVs of $1 \mathrm{mM}$ of $1^{11}$ in DCM containing $0.1 \mathrm{M}$ TBAH starting at the open circuit potential (left) and after holding the potential at $1.4 \mathrm{~V}$ for 2 minutes before the scan (right). Arrows indicate initial scan direction, color code denote scan rate $(\mathrm{mV} / \mathrm{s})$ : Black: $50 \mathrm{mV} / \mathrm{s}$, red: $70 \mathrm{mV} / \mathrm{s}$, green: $100 \mathrm{mV} / \mathrm{s}$, blue: $200 \mathrm{mV} / \mathrm{s}$, turquoise: $300 \mathrm{mV} / \mathrm{s}$, pink: $400 \mathrm{mV} / \mathrm{s}$, yellow: $500 \mathrm{mV} / \mathrm{s}$, dark green: $600 \mathrm{mV} / \mathrm{s}$, dark blue: $700 \mathrm{mV} / \mathrm{s}$, purple: $800 \mathrm{mV} / \mathrm{s}$ and marron: $1000 \mathrm{mV} / \mathrm{s}$.

Analogously to complex $\mathbf{1}^{11}$, complex $\mathbf{2}^{\text {"I }}$ also shows two electrochemically quasi-reversible redox waves at $E_{1 / 2}^{1}{ }^{111 / 1}=1.06 \mathrm{~V}(\Delta E=96 \mathrm{mV})$ and $E_{1 / 2}^{2}{ }^{111 / 1 /}=0.54 \mathrm{~V}(\Delta E=60 \mathrm{mV})$ corresponding

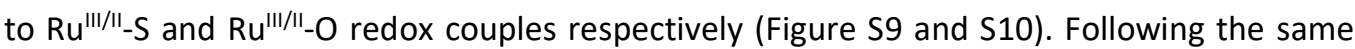
mathematical methodology, we calculated all the equilibrium and rate constants associated with the square mechanism of Scheme 2 for $\mathbf{2}^{\prime \prime}$. All these data are summarized in Table 1 together with the results of $\mathbf{1}^{11}$ and other relevant compounds reported in the literature.

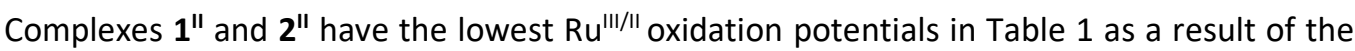
high sigma-donation of the carboxylate groups in the pdc ligand (compare entries 1 and 2 with entries 3-7). Interestingly the complexes having only one DMSO, such as $2^{\prime \prime}$, show slower $K^{\prime \prime}{ }_{\mathrm{O}} \rightarrow \mathrm{S}$ rate as compared to the complexes having two DMSO ligands such as $\mathbf{1}^{11}$ with the exception of complex cis,trans-[Ru(HPhpp)(DMSO $\left.)_{2} \mathrm{Cl}_{2}\right]$ in entry 5 (where HPpp is 2-(5-phenyl- $1 \mathrm{H}$ pyrazol-3-yl)pyridine). Although it is not trivial to compare thermodynamic and kinetic values of complexes with distinct coordination sphere and different relative disposition of chlorido 
and DMSO ligands, a general trend is observed for all the complexes in Table 1; the values of the linkage isomerization constants $\mathrm{K}_{\mathrm{O}}^{\mathrm{N}} \rightarrow \mathrm{S}$ are very high, in the order of $10^{8}-10^{12}$, indicating that Ru"-O species are much less stable and convert to the Ru"-S at low oxidation state. On the other hand, the tendency to isomerize for $\mathrm{Ru}^{\text {III }}-\mathrm{S}$ to the corresponding $\mathrm{Ru}^{\mathrm{III}}-\mathrm{O}$ is less favored for all complexes with equilibrium constants in the range of $\mathrm{K}^{\mathrm{II}} \mathrm{s} \rightarrow 0$ 0.61-7.8.

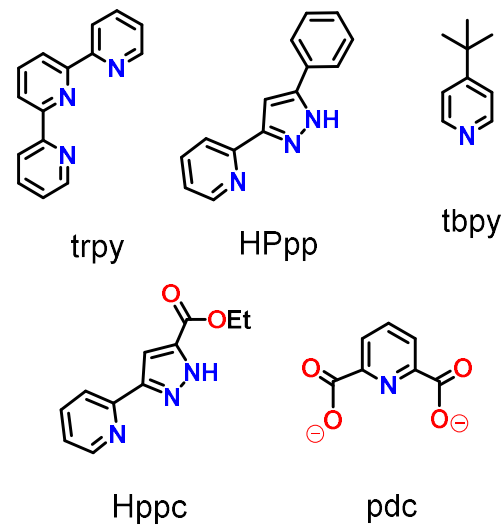

Chart 1. Ligand labels for the Ru-DMSO complexes in Table 1 
Table 1. Thermodynamics and kinetics data for the $\mathrm{S} \rightarrow \mathrm{O}$ linkage isomerization process of complexes $\mathbf{1}^{11}$ and $\mathbf{2}^{11}$ and related compounds reported in the literature.

\begin{tabular}{|c|c|c|c|c|c|c|c|c|c|}
\hline Entry & Complex & $E_{1 / 2}(\mathrm{Ru}-\mathrm{S})^{\mathrm{a}}$ & $E_{1 / 2}(\mathrm{Ru}-\mathrm{O})^{\mathrm{a}}$ & $K^{\prime \prime \prime \prime}(S \rightarrow 0)$ & $k^{\prime \prime \prime} \mathrm{o} \rightarrow 5\left[\mathrm{~s}^{-1}\right]$ & $k^{\prime \prime \prime} \mathrm{s} \rightarrow 0\left[\mathrm{~s}^{-1}\right]$ & $K^{\prime \prime}(0 \rightarrow s)$ & $k^{\prime \prime} \mathrm{O} \rightarrow \mathrm{s}\left[\mathrm{s}^{-1}\right]$ & $k^{\prime \prime}{ }_{\mathrm{s} \rightarrow \mathrm{O}}\left[\mathrm{s}^{-1}\right]$ \\
\hline $1^{\mathrm{b}}$ & {$\left[\mathrm{Ru}(\mathrm{pdc})(\mathrm{DMSO})_{2} \mathrm{Cl}\right] ; \mathbf{1}^{11}$} & 0.96 & 0.26 & $1.67 \pm 0.02$ & $5.2 \times 10^{-1}$ & $9.2 \times 10^{-1}$ & $5.9 \times 10^{11}$ & $(9.4 \pm 0.1) \times 10^{-2}$ & $1.6 \times 10^{-13}$ \\
\hline $2^{\mathrm{b}}$ & [Ru(pdc)(bpy)(DMSO)], 2" & 1.06 & 0.54 & $1.11 \pm 0.05$ & $8.9 \times 10^{-1}$ & $9.8 \times 10^{-1}$ & $8.0 \times 10^{8}$ & $(6.9 \pm 0.5) \times 10^{-2}$ & $1.2 \times 10^{-10}$ \\
\hline $3^{35}$ & $\begin{array}{c}\text { out- } \\
{[\mathrm{Ru}(\mathrm{HPpp})(\operatorname{trpy})(\mathrm{DMSO})]^{+, c}}\end{array}$ & 1.22 & 0.65 & 7.8 & $7.7 \times 10^{-2}$ & $6.0 \times 10^{-1}$ & $5.5 \times 10^{8}$ & $2.5 \times 10^{-1}$ & $4.6 \times 10^{-10}$ \\
\hline $5^{36}$ & $\begin{array}{c}\text { cis, trans- } \\
{\left[\mathrm{Ru}(\mathrm{HPpp})(\mathrm{DMSO})_{2} \mathrm{Cl}_{2}\right]^{\mathrm{c}}}\end{array}$ & 1.22 & 0.63 & 3.9 & $5.7 \times 10^{-2}$ & $2.2 \times 10^{-1}$ & $5.3 \times 10^{8}$ & $8.7 \times 10^{-2}$ & $1.6 \times 10^{-10}$ \\
\hline $6^{33}$ & $\begin{array}{c}\text { cis(in),cis(out)- } \\
{\left[\mathrm{Ru}(\mathrm{Hppc})(\mathrm{DMSO})_{2} \mathrm{Cl}_{2}\right]^{\mathrm{d}}}\end{array}$ & 1.37 & 0.69 & 2.4 & $2.0 \times 10^{-1}$ & $4.9 \times 10^{-1}$ & $2.1 \times 10^{+11}$ & $9.3 \times 10^{-2}$ & $4.5 \times 10^{-13}$ \\
\hline
\end{tabular}




\section{Redox Behavior of Dimeric Compound $5^{\prime \prime \prime \prime \prime I I ~}$}

The oxo bridged dinuclear complex $5^{111,111}$ shows two one-electron reversible waves at

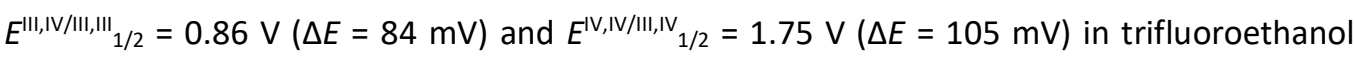
solvent containing 0.1 M TBAH (Figure 5). The high reversibility of both redox processes highlight the stability of the dimeric structure of 5, that doesn't rearrange or react upon oxidation in organic solvents.

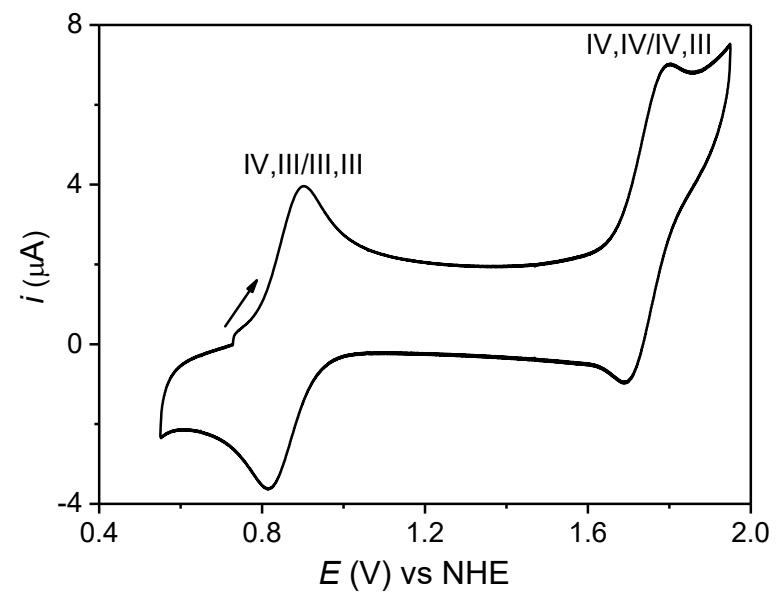

Figure 5. $\mathrm{CV}$ of $0.5 \mathrm{mM}$ of $5^{111, \mathrm{III}}$ in trifluoroethanol containing $0.1 \mathrm{M}$ TBAH.

\section{3-3-Electrochemistry of $5^{111,111}$ in Aqueous Solution}

\section{Conversion of $5^{\prime \prime \prime \prime \prime I I I ~ i n t o ~} 4^{\prime \prime}$}

The redox properties of the oxo-bridged dimer $5^{\mathrm{III}, \mathrm{II}}$ in aqueous solution were analysed in $\mathrm{pH}$ 1 triflic acid solution (Figure 6). It shows a one-electron oxidation wave at $E_{1 / 2}=0.85 \mathrm{~V}(\Delta E=$ $67 \mathrm{mV}$ ) associated with the $\mathrm{Ru}^{\mathrm{IV}}-\mathrm{O}-\mathrm{Ru}^{\mathrm{II \prime}} / \mathrm{Ru}^{\mathrm{III}}-\mathrm{O}-\mathrm{Ru} \mathrm{III}^{\mathrm{II}}$ redox couple, that is consistent with that observed in organic solvents in Figure 5. A subsequent cathodic scan all the way down to 0.05 $V$ shows a chemically irreversible wave at $E_{\mathrm{p}, \mathrm{c}}=0.30 \mathrm{~V}$, that we attribute to a $2 \mathrm{e}^{-} / 1 \mathrm{H}^{+}$transfer as reported for similar complexes that also contain a dinuclear oxo-bridged motive, which is prone to protonation upon reduction. ${ }^{29}$ This proton-coupled electron transfer (PCET) process is followed by the breaking of the resulting $\mathrm{Ru}-\mathrm{OH}-\mathrm{Ru}$ bridge and the formation of the corresponding mononuclear complex $\left[R u^{\prime \prime}\left(p d c-\mathrm{K}^{3}-\mathrm{N}^{1} \mathrm{O}^{2}\right)(\mathrm{bpy})\left(\mathrm{H}_{2} \mathrm{O}\right)\right], 4^{\prime \prime}$ as indicated in equations 2-4. Upon repetitive CV cycles in the potential range from $0.05 \mathrm{~V}$ to $0.95 \mathrm{~V}$, a new redox wave appears at $E^{11 / / 1}{ }_{1 / 2}=0.52 \mathrm{~V}$ with concomitant disappearance of the redox couples associated with $\mathbf{5}^{\mathbf{I I}, \mathrm{II}}$ (Figure 6 , left). This can be further proved by a quick control potential 
electrolysis, carried out at $E_{\text {app }}=0.05 \mathrm{~V}$ for $10 \mathrm{~min}$. As can be seen from Figure 6 (right) all the starting complex $5^{11,111}$ completely converts to the new complex $4^{\prime \prime}$.

$$
\begin{gathered}
\mathrm{Ru}^{\mathrm{III}}-\mathrm{O}-\mathrm{Ru}^{\mathrm{III}}\left(\mathbf{5}^{\mathrm{III}, \mathrm{III}}\right)-1 \mathrm{e}^{-} \rightarrow \mathrm{Ru}^{\mathrm{III}}-\mathrm{O}-\mathrm{Ru}^{\mathrm{IV}} \quad E_{\frac{1}{2}}=0.85 \mathrm{~V} \\
\mathrm{Ru}^{\mathrm{III}}-\mathrm{O}-\mathrm{Ru}^{\mathrm{III}}\left(\mathbf{5}^{\mathrm{III}, \mathrm{III}}\right)+2 \mathrm{e}^{-}+1 \mathrm{H}^{+} \rightarrow \mathrm{Ru}^{\mathrm{II}}-(\mathrm{OH})-\mathrm{Ru}^{\mathrm{II}} \quad E_{\frac{1}{2}}=0.3 \mathrm{~V} \\
\mathrm{Ru}^{\mathrm{II}}-(\mathrm{OH})-\mathrm{Ru}^{\mathrm{II}}+\mathrm{H}_{2} \mathrm{O}+1 \mathrm{H}^{+} \rightarrow 2 \mathrm{Ru}^{\mathrm{II}}-\mathrm{OH}_{2}\left(\mathbf{4}^{\mathrm{II}}\right)
\end{gathered}
$$
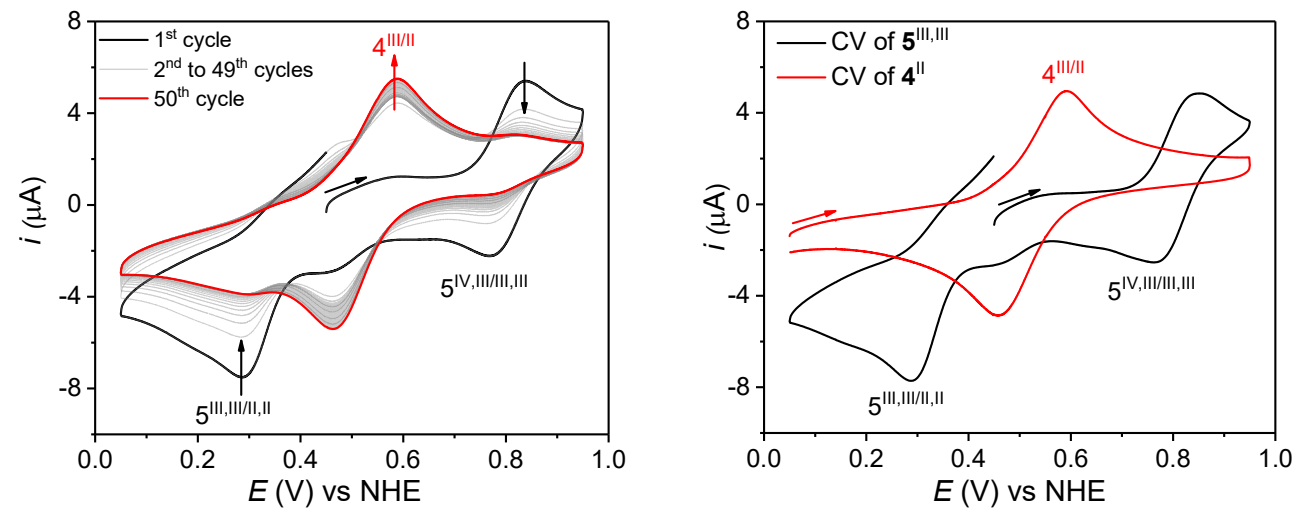

Figure 6. Left) Repetitive CV experiments of $1 \mathrm{mM}$ of $5^{\mathrm{III}, \mathrm{III}}$ in $\mathrm{pH} 1.0$ triflic acid solution showing the generation of the new complex $4^{\text {" }}$ after breaking the oxo-bridge (see equations $2-4$ in main text); $1^{\text {st }}$ cycle (black), $2^{\text {nd }}$ to $49^{\text {th }}$ cycles (grey) and $50^{\text {th }}$ cycle (red), vertical black arrows indicate disappearance of the waves associated with $5^{\mathrm{III}, \mathrm{III}}$ and red vertical arrow indicates appearance of the redox waves with $4^{\prime \prime}$. Right) CV of complex $5^{\mathrm{II \prime \prime \prime II}}$ before (black) and after (red) a CPE at $E_{\text {app }}=0.05 \mathrm{~V}$, showing clean conversion to complex $4^{\prime \prime}$.

\section{Electrochemistry of $4^{\prime \prime}$ and Water Oxidation Catalysis}

Complex $4^{\prime \prime}$ is a mononuclear Ru- $\mathrm{OH}_{2}$ type of complex that has been previously proposed to act as a water oxidation catalyst but it has never been prepared in pure form due to the low stability upon work up procedures from the reaction starting with the chlorido precursor $3^{\prime \prime \prime}$ (Scheme 1). ${ }^{3}$ Thus, the in situ generation of $4^{\prime \prime}$ from the dimeric complex $5^{111, \mathrm{ll}}$ is a useful, alternative methodology to isolate this complex in solution and to fully analyze its electrochemical behavior as well as the kinetic data associated with their capacity to oxidize water.

As shown in Figure 7, compound 4" shows two one-electron waves at $E_{1 / 2}=0.52 \mathrm{~V}(\Delta E=130$ $\mathrm{mV}$ ) and $E_{\mathrm{p}, \mathrm{a}}=1.19 \mathrm{~V}$ corresponding to the III/II and IV/III redox couples respectively. Both waves are $\mathrm{pH}$ dependent as expected for a Ru-aquo type of complex that is involved in PCET (Figure S11). The Ru ${ }^{I V / I I I}$ wave is not reversible because it is partially overlapping with a third 
irreversible wave that is $\mathrm{pH}$ independent and that we attribute to the $\mathrm{Ru}^{\mathrm{V} / \mathrm{V}}$ couple followed by electrocatalytic oxidation of water. A manometry experiment using a $1 \mathrm{mM}$ solution of $4^{\prime \prime}$ generated electrochemically and $100 \mathrm{mM}$ of $\left(\mathrm{NH}_{4}\right)_{2}\left[\mathrm{Ce}\left(\mathrm{NO}_{3}\right)_{6}\right]$ as sacrificial electron acceptor in $\mathrm{pH} 1$ shows the evolution of gas with a calculated turnover number of TON = 1.2 (Figure S1). The poor catalytic activity observed under this chemical oxidation is consistent with the limited catalytic current observed in the CV of Figure 7, which hardly exceeds the current intensity equivalent to one-electron transfer.

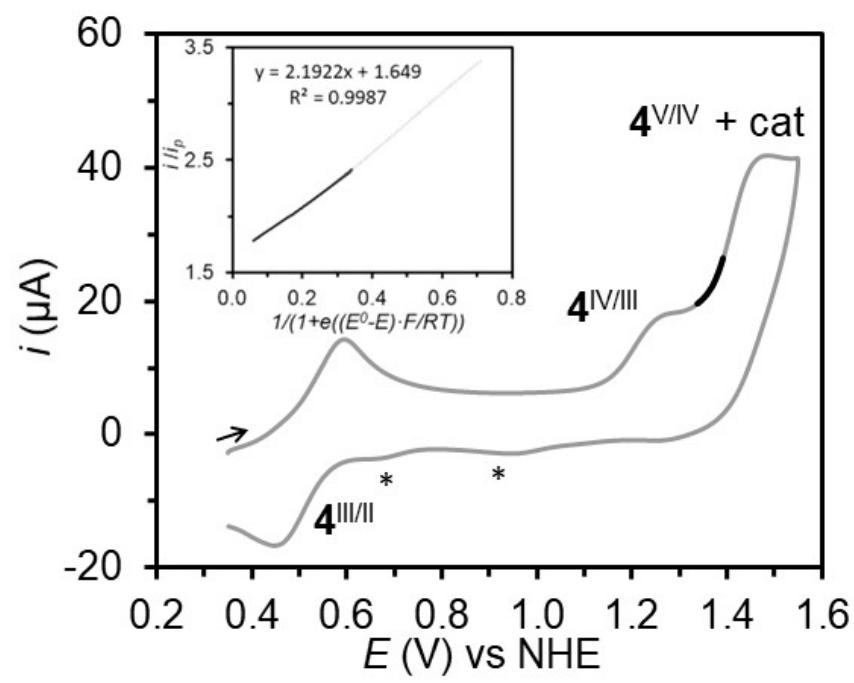

Figure 7. Cyclic voltammetry of $4^{\prime \prime}$ in $\mathrm{pH} 1$ generated in situ from $5^{\mathrm{III}, \mathrm{III}}$ after a CPE at $E_{\mathrm{app}}=0.05 \mathrm{~V}$ for $10 \mathrm{~min}(\mathrm{scan}$ rate $=0.1 \mathrm{~V} / \mathrm{s})$. Asterisks indicate unidentified species. Inset: foot of the wave analysis (FOWA) of 4". The grey line represents the experimental data used for the FOWA and the black solid line shows the experimental data used for the extraction of TOFmax.

The Pourbaix diagram of complex $4^{11}$ in Figure 8 is fully consistent with reported data ${ }^{3}$ and reveals that the $\left[\mathrm{Ru}^{\mathrm{III}}-\mathrm{OH}\right] /\left[\mathrm{Ru}^{\mathrm{II}}-\mathrm{OH}_{2}\right]$ and $\left[\mathrm{Ru}^{\mathrm{IV}}-\mathrm{O}\right] /\left[\mathrm{Ru} \mathrm{u}^{\mathrm{II}}-\mathrm{OH}\right]$ redox processes each changes by approximately $59 \mathrm{mV}$ per $\mathrm{pH}$ decade over a large $\mathrm{pH}$ range $(11>\mathrm{pH}>4)$. The oxidation of 4 " at $\mathrm{pH}<4$ is not associated with the loss of a proton based on the $\mathrm{pH}$-independent behavior of the $\left[\mathrm{Ru}^{\mathrm{III}}-\mathrm{OH}_{2}\right] /\left[\mathrm{Ru}^{\prime \prime}-\mathrm{OH}_{2}\right]$ redox couple. Consequently, the higher oxidation step is accompanied with the loss of two protons (i.e. $\left[\mathrm{Ru}^{\mathrm{IV}}-\mathrm{O}\right] /\left[\mathrm{Ru}^{\mathrm{III}}-\mathrm{OH}_{2}\right]$ ) in strongly acidic medium. This assignment is corroborated by the slope of $-118 \mathrm{mV} / \mathrm{pH}$ below $\mathrm{pH} 4.0$ for $\mathbf{4}^{\prime \prime \prime}$. At $\mathrm{pH}>11$, the potentials for the $\mathrm{Ru}^{\mathrm{II} / / \mathrm{I}}$ become $\mathrm{pH}$ independent as a consequence of a loss of a proton from $\left[\mathrm{Ru}^{\mathrm{II}}-\mathrm{OH}_{2}\right]$ with $\mathrm{p} K_{\mathrm{a}} \approx 11$. The $\left[\mathrm{Ru}^{\mathrm{v}}-\mathrm{O}\right]^{+} /\left[\mathrm{Ru}^{\mathrm{IV}}-\mathrm{O}\right]$ redox couple remains relatively constant at $\sim 1.41 \mathrm{~V}$ over the whole $\mathrm{pH} 0-13$ range. The $\mathrm{p} K_{\mathrm{a}}{ }^{\prime \prime \prime}$ value for the $\left[\mathrm{Ru} \mathrm{u}^{\prime \prime \prime}-\mathrm{OH}\right]$ derived from $4^{\prime \prime}$ is higher as compared to other Ru-aquo complexes with neutral ligand such as 
$\left[\mathrm{Ru}(\operatorname{trpy})(\mathrm{bpy})\left(\mathrm{OH}_{2}\right)\right]^{2+}\left(\mathrm{p} K_{\mathrm{a}}{ }^{\prime \prime \prime}=4\right.$ and 1.7 respectively $),{ }^{37}$ mainly due to the presence of two negatively charged carboxylate groups around the ruthenium center, that makes the complex more basic in nature as expected.

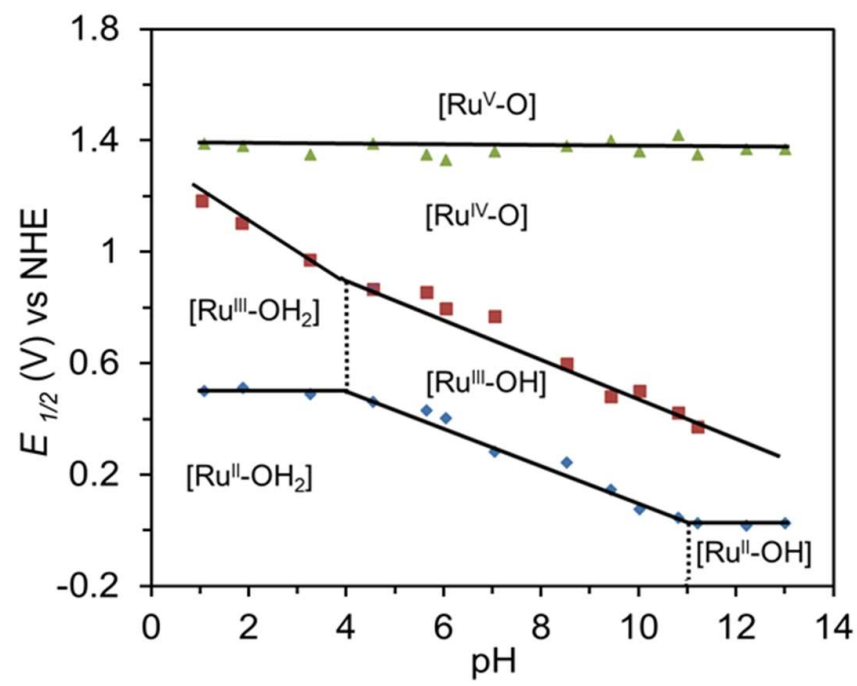

Figure 8. Pourbaix diagram of $4^{\prime \prime}$ generated in situ from $5^{111, I I I}$ after a CPE at $E_{\text {app }}=0.05 \mathrm{~V}$ for $10 \mathrm{~min}$. Black solid horizontal lines indicate the change in redox potentials for the different redox couples at varying $\mathrm{pH}$, whereas the dashed vertical lines indicate $\mathrm{pK}_{\mathrm{a}}$ values. The zone of stability of the different species are indicated only with the Ru symbol, its oxidation state, and the degree of protonation of the aquo ligand. For instance, $\left[\mathrm{Ru}^{\mathrm{IV}}-\mathrm{O}\right]$ is used to indicate the zone of stability of complex $4^{\mathrm{IV}}\left[\mathrm{Ru}^{\mathrm{IV}}(\mathrm{O})\left(\mathrm{pdc}-\mathrm{K}^{3}-\mathrm{N}^{1} \mathrm{O}^{2}\right)(\mathrm{bpy})\right]$.

A "foot of the wave analysis" (FOWA) of the CV in Figure 7 allowed us to calculate an estimate value of the apparent rate constant for the water oxidation catalytic process. Assuming a unimolecular mechanism, this method developed by Sáveant and coworkers ${ }^{38,39}$ consists of using the relationship in equation 5 ,

$$
\frac{i}{i_{p}}=\frac{4 * 2.24 * \sqrt{\frac{\mathrm{RT} \text { obs }}{\mathrm{Fv}}}}{1+\exp \left(\frac{\mathrm{F}\left(E_{\mathrm{P}}^{0} / \mathrm{Q}^{-E}\right)}{\mathrm{RT}}\right)}
$$

where $k_{\text {obs }}$ is the unimolecular apparent rate constant or maximum turnover frequency $\left(\mathrm{TOF}_{\text {max }}\right), i$ is the current intensity in the presence of substrate, $i_{\mathrm{p}}$ is the current intensity in the absence of substrate (we approximate this current to the current associated with the Ru $\mathrm{u}^{\text {IIIII }}$ couple), $E_{\mathrm{P} / \mathrm{Q}}^{0}$ is the standard potential for the redox couple where the catalysis starts $(1.41 \mathrm{~V}$ for 4 " extracted from the DPVs in Figure S11), F is the faraday constant, $v$ is the scan rate, and $\mathrm{R}$ is $8.314 \mathrm{~J} \mathrm{~mol}^{-1} \mathrm{~K}^{-1}$. 
From the plot of $i / i_{\mathrm{p}}$ versus $1 /\left\{1+\exp \left[(\mathrm{F} / \mathrm{RT})\left(E_{\mathrm{P} / \mathrm{Q}}-E\right)\right]\right\}$ shown in Figure 7 a $\mathrm{TOF}_{\max }=0.2 \mathrm{~s}^{-1}$ is obtained. This value is comparable to the catalytic rates of relevant ruthenium-aquo complexes reported in the literature, that are believed to follow a mechanistic pathway where the $\mathrm{O}-\mathrm{O}$ bond formation through a nucleophilic attack of a water molecule to the $\mathrm{Ru}^{\mathrm{V}}=\mathrm{O}$ species is the rate determining step of the reaction (Table 2, entries 1-6). Importantly, the overpotential of the catalytic reaction at $\mathrm{pH} 1$, dictated by the $E_{1 / 2}\left(\mathrm{Ru}^{\mathrm{V} / \mathrm{VV}}\right)$, is only $240 \mathrm{mV}$, being one of the lowest ever reported in the literature. This is a consequence of the two carboxylate groups in the pdc ligand that provide high electron density to the ruthenium center, allowing to reach higher oxidation states within a narrow potential range. This record low value of overpotential is only overcome by complex $\left[\mathrm{Ru}^{\mathrm{IV}}(\mathrm{bda})(4-\mathrm{Pic})_{2}(\mathrm{O})\right]$ in Table 1 and its derivatives (compare entries 8 and 9, where bda is [2,2'-bipyridine]-6,6'-dicarboxylato and 4-pic is 4-picoline), that also contain two carboxylate groups in the bda ligand framework, but also the possibility to reach seven coordination intermediate species that give extrastabilization of the high valent ruthenium intermediates involved in the catalysis. ${ }^{17}$ In contrast, catalyst 4" undergoes a catalytic pathway where only six coordinated species are involved, as suggested in a previous reported work. $^{3}$

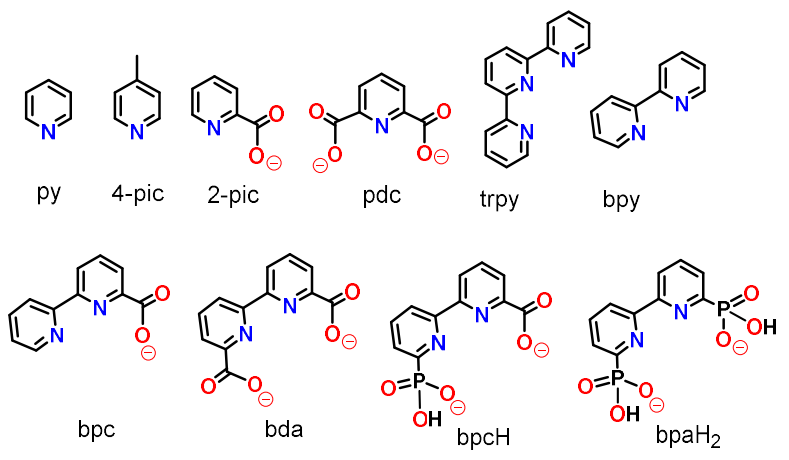

Chart 2. Ligand labels for the Ru-complexes in Table 2. 
Table 2. Electrochemical and water oxidation catalytic data of $4^{\text {" }}$ and selected complexes reported in the literature at $\mathrm{pH} 1$.

\begin{tabular}{|c|c|c|c|c|c|c|c|}
\hline Entry & Complex & $\mathrm{N}^{\mathrm{a}}$ & $E_{1 / 2}\left(\mathrm{Ru}^{\mathrm{III} / \mathrm{II}}\right)(\mathrm{V})$ & $E_{1 / 2}\left(\mathrm{Ru}^{\mathrm{IV} / \mathrm{III}}\right)(\mathrm{V})$ & $E_{1 / 2}\left(\mathrm{Ru}^{\mathrm{V} / \mathrm{IV}}\right)(\mathrm{V})$ & $\operatorname{TOF}^{\mathrm{b}}\left(\mathrm{s}^{-1}\right)$ & $\operatorname{TOF}_{\max }{ }^{c}\left(\mathrm{~s}^{-1}\right)$ \\
\hline $1^{37}$ & {$\left[\mathrm{Ru}^{\prime \prime}(\operatorname{trpy})(\mathrm{bpy})\left(\mathrm{H}_{2} \mathrm{O}\right)\right]^{2+}$} & 0 & 1.06 & 1.22 & 1.92 & 0.01 & $d$ \\
\hline $2^{40}$ & {$\left[\mathrm{Ru}^{\prime \prime}(\mathrm{bpc})(\mathrm{bpy})\left(\mathrm{H}_{2} \mathrm{O}\right)\right]^{+}$} & 1 & 0.81 & 1.29 & 1.57 & 0.16 & $d$ \\
\hline $3^{41}$ & cis-[Ru"l(trpy)(qc)( $\left.\left.\mathrm{H}_{2} \mathrm{O}\right)\right]^{+}$ & 1 & 0.82 & 1.36 & 1.71 & $d$ & 6.8 \\
\hline $4^{41}$ & trans-[Ru" $\left.(\operatorname{trpy})(q c)\left(\mathrm{H}_{2} \mathrm{O}\right)\right]^{+}$ & 1 & 0.67 & 1.20 & 1.62 & 0.68 & 4.2 \\
\hline $5^{41}$ & cis-[Ru"l(trpy)(2-pic) $\left.\left(\mathrm{H}_{2} \mathrm{O}\right)\right]^{+}$ & 1 & 0.86 & 1.31 & 1.67 & 0.11 & 0.3 \\
\hline $6^{41}$ & trans-[Ru"(trpy)(2-pic)( $\left.\left.\mathrm{H}_{2} \mathrm{O}\right)\right]^{+}$ & 1 & 0.76 & 1.09 & 1.60 & 0.24 & 1.2 \\
\hline $7^{15}$ & {$\left[\mathrm{Ru}^{\mathrm{IV}}(\mathrm{bda})(4-\mathrm{pic})_{2}(\mathrm{O})\right]$} & 2 & 0.61 & 1.1 & 1.35 & 33 & $11^{\mathrm{e}}$ \\
\hline $8^{42}$ & {$\left[\mathrm{Ru}^{\mathrm{IV}}\left(\mathrm{bpaH}_{2}\right)(4-\mathrm{pic})_{2}(\mathrm{O})\right]$} & 2 & 0.71 & 1.57 & d & 0.65 & $d$ \\
\hline $9^{43}$ & {$\left[\mathrm{Ru}^{\mathrm{l} V}(\mathrm{bpcH})(4-\mathrm{pic})_{2}(\mathrm{O})\right]$} & 2 & 0.65 & 1.41 & 1.61 & 58 & $d$ \\
\hline $10^{f}$ & {$\left[\mathrm{Ru}^{\prime \prime}(\mathrm{pdc})(\mathrm{bpy})\left(\mathrm{H}_{2} \mathrm{O}\right)\right]^{+}, 4^{\prime \prime}$} & 2 & 0.52 & 1.19 & 1.41 & 0.01 & 0.2 \\
\hline
\end{tabular}




\section{Conclusions}

In this work, the synthesis of two unprecedented ruthenium complexes containing the meridional 2,6-pyridinedicarboxylato (pdc) ligand [Ru" $\left.\left(p d c-\mathrm{K}^{3}-\mathrm{N}^{1} \mathrm{O}^{2}\right)(\mathrm{bpy})(\mathrm{DMSO})\right], \mathbf{2}^{\prime \prime}$ and $\left\{\left[R u^{\prime \prime \prime}\left(p d c-\mathrm{K}^{3}-\mathrm{N}^{1} \mathrm{O}^{2}\right)(\mathrm{bpy})\right]_{2}(\mu-\mathrm{O})\right\}, 5^{111, \prime \prime \prime}$ has been described. Both complexes have been fully characterized by spectroscopic, single crystal x-ray diffraction and electrochemical techniques.

Complex 2" and its precursor $\left[\mathrm{Ru}^{\prime \prime}\left(p d c-\mathrm{R}^{3}-\mathrm{N}^{1} \mathrm{O}^{2}\right)(\mathrm{DMSO})_{2} \mathrm{Cl}\right]$; 1" show Ru-DMSO linkage isomerization processes (Ru-S/Ru-O) upon oxidation. Cyclic voltammetry experiments allowed us to quantitatively describe all the thermodynamic and kinetic constants involved in this process for both compounds and the values have been compared with related Ru-DMSO complexes reported in the literature. A general trend observed from this comparison is that the linkage isomerization constants at oxidation state $\mathrm{Ru}^{\prime \prime}\left(\mathrm{K}_{\mathrm{O}} \mathrm{O} \rightarrow \mathrm{S}\right)$ are all very high, in the order of $10^{8}-10^{12}$, indicating that $\mathrm{Ru}^{\prime \prime}-\mathrm{O}$ species was unstable and immediately isomerizes to the Ru"-S.

The dimeric complex $5^{\mathrm{III}, \mathrm{II}}$ is characterized by a bridging oxo group, whose Ru-O-Ru angle of $126^{\circ}$ determines a diamagnetic electronic configuration $\left(\pi_{1}{ }^{b}\right)^{2}\left(\pi_{2}^{b}\right)^{2}\left(\pi_{1}{ }^{n b}\right)^{2}\left(\pi_{2}{ }^{n b}\right)^{2}\left(\pi_{1}{ }^{*}\right)\left(\pi_{2}{ }^{*}\right)^{0}$, allowing to analyze this complex with NMR techniques. Upon reduction in $\mathrm{pH} 1$ aqueous solution, compound $5^{\text {III,III }}$ converts to the monomeric derivative $4^{\prime \prime}$ [ $\mathrm{Ru}$ (1) $\left.\left(\mathrm{pdc}-\mathrm{K}^{3}-\mathrm{N}^{1} \mathrm{O}^{2}\right)(\mathrm{bpy})\left(\mathrm{OH}_{2}\right)\right]$, a Ruaquo complex that is active for the water oxidation catalysis with an overpotential of only 240 $\mathrm{mV}$ in acidic $\mathrm{pH}$ due to the presence of two carboxylates groups connected to the ruthenium with $\mathrm{TOF}_{\max }=0.2 \mathrm{~s}^{-1}$.

\section{Acknowledgements}

Support from MINECO, FEDER and AGAUR are gratefully acknowledged through grants CTQ2016-80058-R, CTQ2015-73028-EXP, SEV 2013-0319, ENE2016-82025-REDT, CTQ201681923-REDC, and 2017-SGR-1631.

\section{Supporting Information}

Additional spectroscopic, mass spectrometry, structural and electrochemistry data. 


\section{References}

${ }^{1}$ Matheu, R.; Garrido-Barros, P.; Gil-Sepulcre, M.; Ertem, M. Z.; Sala, X.; Gimbert-Suriñach, C.; Llobet, A. The Development of Molecular Water Oxidation Catalysts. Nat. Rev. Chem. 2019, 3, 331-341.

${ }^{2}$ Berardi, S.; Drouet, S.; Francàs, L.; Gimbert-Suriñach, C.; Guttentag, M.; Richmond, C.; Stoll, T.; Llobet, A. Molecular Artificial Photosynthesis. Chem. Soc. Rev. 2014, 43, 7501-7519.

${ }^{3}$ Hoque, M. A.; Benet-Buchholz, J.; Llobet, A.; Gimbert-Suriñach, C. Catalytic Oxidation of Water to Dioxygen by Mononuclear Ru Complexes Bearing a 2,6-Pyridinedicarboxylato Ligand. ChemSusChem. 2019, 12, 1949-1957.

${ }^{4}$ Shatskiy, A.; Bardin, A. A.; Oschmann, M.; Matheu, R.; Benet-Buchholz, J.; Eriksson, L.; Kärkäs, M. D.; Johnston, E. V.; Gimbert-Suriñach, C.; Llobet, A.; Åkermark, B. Electrochemically Driven Water Oxidation by a Highly Active Ruthenium-Based Catalyst. ChemSusChem. 2019, 12, 22512262.

${ }^{5}$ Savini, A.; Bellachioma, G.; Bolaño, S.; Rocchigiani, L.; Zuccaccia, C.; Zuccaccia, D.; Macchioni, A. Iridium-Edta as an Efficient and Readily Available Catalyst for Water Oxidation. ChemSusChem. 2012, 5, 1415-1419.

6 Yagi, M.; Narita, K. Catalytic O2 Evolution from Water Induced by Adsorption of $\left[\left(\mathrm{OH}_{2}\right)(\mathrm{Terpy}) \mathrm{Mn}(\mu-\mathrm{O})_{2} \mathrm{Mn}(\mathrm{Terpy})\left(\mathrm{OH}_{2}\right)\right]^{3+}$ Complex onto Clay Compounds. J. Am. Chem. Soc. 2004, 126, 8084-8085.

${ }^{7}$ Ellis, W. C.; McDaniel, N. D.; Bernhard, S.; Collins, T. J. Fast Water Oxidation Using Iron. J. Am. Chem. Soc. 2010, 132, 10990-10991.

${ }^{8}$ Kottrup, K. G.; D’Agostini, S.; van Langevelde, P. H.; Siegler, M. A.; Hetterscheid, D. G. H. Catalytic Activity of an Iron-Based Water Oxidation Catalyst: Substrate Effects of Graphitic Electrodes. ACS Catal. 2018, 8, 1052-1061.

${ }^{9}$ Rigsby, M. L.; Mandal, S.; Nam, W.; Spencer, L. C.; Llobet, A.; Stahl, S. S. Cobalt Analogs of RuBased Water Oxidation Catalysts: Overcoming Thermodynamic Instability and Kinetic Lability to Achieve Electrocatalytic $\mathrm{O}_{2}$ Evolution. Chem. Sci. 2012, 3, 3058-3062.

${ }^{10}$ Zhang, M.-T.; Chen, Z.; Kang, P.; Meyer, T. J. Electrocatalytic Water Oxidation with a Copper(II) Polypeptide Complex. J. Am. Chem. Soc. 2013, 135, 2048-2051.

${ }^{11}$ Garrido-Barros, P.; Funes-Ardoiz, I.; Drouet, S.; Benet-Buchholz, J.; Maseras, F.; Llobet, A. Redox Non-Innocent Ligand Controls Water Oxidation Overpotential in a New Family of Mononuclear Cu-Based Efficient Catalysts. J. Am. Chem. Soc. 2015, 137, 6758-6761.

12 Tong, L.; Thummel, R. P. Mononuclear ruthenium polypyridine complexes that catalyze water oxidation. Chem. Sci. 2016, 7, 6591-6603.

${ }^{13}$ Matheu, R.; Ertem, M. Z.; Gimbert-Suriñach, C.; Sala, X.; Llobet, A. Seven Coordinated Molecular Ruthenium-Water Oxidation Catalysts: A Coordination Chemistry Journey. Chem. Rev. 2019, 119, 3453-3471.

${ }^{14}$ Zhang, B.; Sun, L. Ru-Bda: Unique Molecular Water-Oxidation Catalysts with Distortion Induced Open Site and Negatively Charged Ligands. J. Am. Chem. Soc. 2019, 141, 5565-5580.

${ }^{15}$ Duan, L.; Bozoglian, F.; Mandal, S.; Stewart, B.; Privalov, T.; Llobet, A.; Sun, L. A Molecular Ruthenium Catalyst with Water-Oxidation Activity Comparable to That of Photosystem II. Nat. Chem. 2012, 4, 418-423.

${ }^{16}$ Richmond, C. J.; Matheu, R.; Poater, A.; Falivene, L.; Benet-Buchholz, J.; Sala, X.; Cavallo, L.; Llobet, A. Supramolecular Water Oxidation with Ru-Bda-Based Catalysts. Chem. - Eur. J. 2014, 20, 17282-17286.

${ }^{17}$ Matheu, R.; Ertem, M. Z.; Benet-Buchholz, J.; Coronado, E.; Batista, V. S.; Sala, X.; Llobet, A. Intramolecular Proton Transfer Boosts Water Oxidation Catalyzed by a Ru Complex. J. Am. Chem. Soc. 2015, 137, 10786-10795. 
${ }^{18}$ vans, I. P.; Spencer, A.; Wilkinson, G. Dichlorotetrakis(Dimethyl Sulphoxide)Ruthenium(II) and Its Use as a Source Material for Some New Ruthenium(II) Complexes. J. Chem. Soc., Dalton Trans. 1973, 204-209.

19 "Handbook of Analytical Chemistry", L Meites, ed., McGraw Hill, NY (1963). See Sect 5. (http://www.consultrsr.net/resources/ref/refpotls.htm)

${ }^{20}$ Xie, Y.-F.; Zhu, H.; Shi, H.-T.; Jia, A.-Q.; Zhang, Q.-F. Ruthenium Complexes Containing Pyridine2,6-Dicarboxylato Ligands. Inorg. Chim. Acta 2015, 428, 147-153.

${ }^{21}$ Data collection with APEX II version v2013.4-1. Bruker (2007). Bruker AXS Inc., Madison, Wisconsin, USA.

${ }^{22}$ Data reduction with Bruker SAINT version V8.30c. Bruker (2007). Bruker AXS Inc., Madison, Wisconsin, USA.

${ }^{23}$ Blessing, R. An Empirical Correction for Absorption Anisotropy. Acta Crysta. A 1995, 51, 33-38.

${ }^{24}$ Sheldrick, G. Shelxt - Integrated Space-Group and Crystal-Structure Determination. Acta Crysta. A 2015, 71, 3-8.

${ }^{25}$ Hubschle, C. B.; Sheldrick, G. M.; Dittrich, B. Shelxle: A Qt Graphical User Interface for Shelxl. J. Appl. Crystallogr. 2011, 44, 1281-1284.

${ }^{26}$ Sheldrick, G. Crystal Structure Refinement with Shelxl. Acta Cryst. C 2015, 71, 3-8.

${ }^{27}$ An, J.; Duan, L.; Sun, L. Ru Complexes Containing Pyridine Dicarboxylate Ligands: Electronic Effects on Their Catalytic Activity toward Water Oxidation. Faraday Discuss. 2012, 155, 267-275. ${ }^{28}$ Duan, L.; Xu, Y.; Gorlov, M.; Tong, L.; Andersson, S.; Sun, L. Chemical and Photochemical Water Oxidation Catalyzed by Mononuclear Ruthenium Complexes with a Negatively Charged Tridentate Ligand Chem. Eur. J. 2010, 16, 4659-4668.

${ }^{29}$ López, I.; Maji, S.; Benet-Buchholz, J.; Llobet, A. Oxo-Bridge Scenario Behind Single-Site WaterOxidation Catalysts. Inorg. Chem. 2015, 54, 658-666.

30 Ishitani, O.; White, P. S.; Meyer, T. J. Formation of Dinitrogen by Oxidation of $\left[(\text { bpy })_{2}\left(\mathrm{NH}_{3}\right) \mathrm{RuORu}\left(\mathrm{NH}_{3}\right)(\text { bpy })_{2}\right]^{4+}$. Inorg. Chem. 1996, 35, 2167-2168.

31 Lebeau, E. L.; Adeyemi, S. A.; Meyer, T. J. Water Oxidation by $\left[(\text { tpy })\left(\mathrm{H}_{2} \mathrm{O}\right)_{2} \mathrm{Ru}^{\prime \prime \prime} \mathrm{ORu} u^{\prime \prime \prime}\left(\mathrm{H}_{2} \mathrm{O}\right)_{2}(\text { tpy })\right]^{4+}$. Inorg. Chem. 1998, 37, 6476-6484.

32 López, I.; Ertem, M. Z.; Maji, S.; Benet-Buchholz, J.; Keidel, A.; Kuhlmann, U.; Hildebrandt, P.; Cramer, C. J.; Batista, V. S.; Llobet, A. A Self-Improved Water-Oxidation Catalyst: Is One Site Really Enough? Angew. Chem., Int. Ed. 2014, 53, 205-209.

${ }^{33}$ Mognon, L.; Benet-Buchholz, J.; Llobet, A. Single Site Isomeric Ru Wocs with an ElectronWithdrawing Group: Synthesis, Electrochemical Characterization, and Reactivity. Inorg. Chem. 2015, 54, 11948-11957.

${ }^{34}$ Silva, D. O.; Toma, H. E. Linkage Isomerization and Electrochemical Behavior of Two Geometrical Isomers of dichlorobis(dimethylsulfoxide)bis(t-butylpyridine)Ruthenium(II). Can. J. Chem. 1994, 72, 1705-1708.

${ }^{35}$ Benet-Buchholz, J.; Comba, P.; Llobet, A.; Roeser, S.; Vadivelu, P.; Wiesner, S. The Ru $\mathrm{IV}^{\mathrm{IV}}=\mathrm{O}-$ Catalyzed Sulfoxidation: A Gated Mechanism Where $O$ to $S$ Linkage Isomerization Switches between Different Efficiencies. Dalton Trans. 2010, 39, 3315-3320.

${ }^{36}$ Roeser, S.; Maji, S.; Benet-Buchholz, J.; Pons, J.; Llobet, A. Synthesis, Characterization, Reactivity, and Linkage Isomerization of $\mathrm{Ru}(\mathrm{Cl})_{2}(\mathrm{~L})(\mathrm{DMSO})_{2}$ Complexes. Eur. J. Inorg. Chem. 2013, 2013, 232-240.

${ }^{37}$ Takeuchi, K. J.; Thompson, M. S.; Pipes, D. W.; Meyer, T. J. Redox and Spectral Properties of Monooxo Polypyridyl Complexes of Ruthenium and Osmium in Aqueous Media. Inorg. Chem. 1984, 23, 1845-1851.

${ }^{38}$ Costentin, C.; Drouet, S.; Robert, M.; Savéant, J.-M. Turnover Numbers, Turnover Frequencies, and Overpotential in Molecular Catalysis of Electrochemical Reactions. Cyclic Voltammetry and Preparative-Scale Electrolysis. J. Am. Chem. Soc. 2012, 134, 11235-11242.

${ }^{39}$ Matheu, R.; Neudeck, S.; Meyer, F.; Sala, X.; Llobet, A. Foot of the Wave Analysis for Mechanistic Elucidation and Benchmarking Applications in Molecular Water Oxidation Catalysis. ChemSusChem. 2016, 9, 3361-3369. 
40 Tong, L.; Inge, A. K.; Duan, L.; Wang, L.; Zou, X.; Sun, L. Catalytic Water Oxidation by Mononuclear Ru Complexes with an Anionic Ancillary Ligand. Inorg. Chem. 2013, 52, 2505-2518. ${ }^{41}$ Unpublished results

${ }^{42}$ Xie, Y.; Shaffer, D. W.; Lewandowska-Andralojc, A.; Szalda, D. J.; Concepcion, J. J. Water oxidation by ruthenium complexes incorporating multifunctional bipyridyl diphosphonate ligands. Angew. Chem., Int. Ed. 2016, 55, 8067-8071.

${ }^{43}$ Shaffer, D. W.; Xie, Y.; Szalda, D. J.; Concepcion, J. J. Lability and Basicity of BipyridineCarboxylate-Phosphonate Ligand Accelerate Single-Site Water Oxidation by Ruthenium-Based Molecular Catalysts. J. Am. Chem. Soc. 2017, 139, 15347-15355. 
For Table of Contents Only

\section{Synopsis}

The meridional ligand pyridyl-2,6-dicarboxylato (pdc) and the bidentate ligand 2,2'-bipyridine (bpy) have been used to prepare a dimeric ruthenium complex that serves as a precursor of a mononuclear compound with the formula $\left[\mathrm{Ru}(\mathrm{bpy})(\mathrm{pdc})\left(\mathrm{OH}_{2}\right)\right]$, which is an active catalyst for the water oxidation to dioxygen reaction at one of the lowest overpotentials reported to date $(240 \mathrm{mV})$. The catalytic activity of this compound is limited by its transformation to inactive products, including the dimeric precursor.

\section{Graphic}

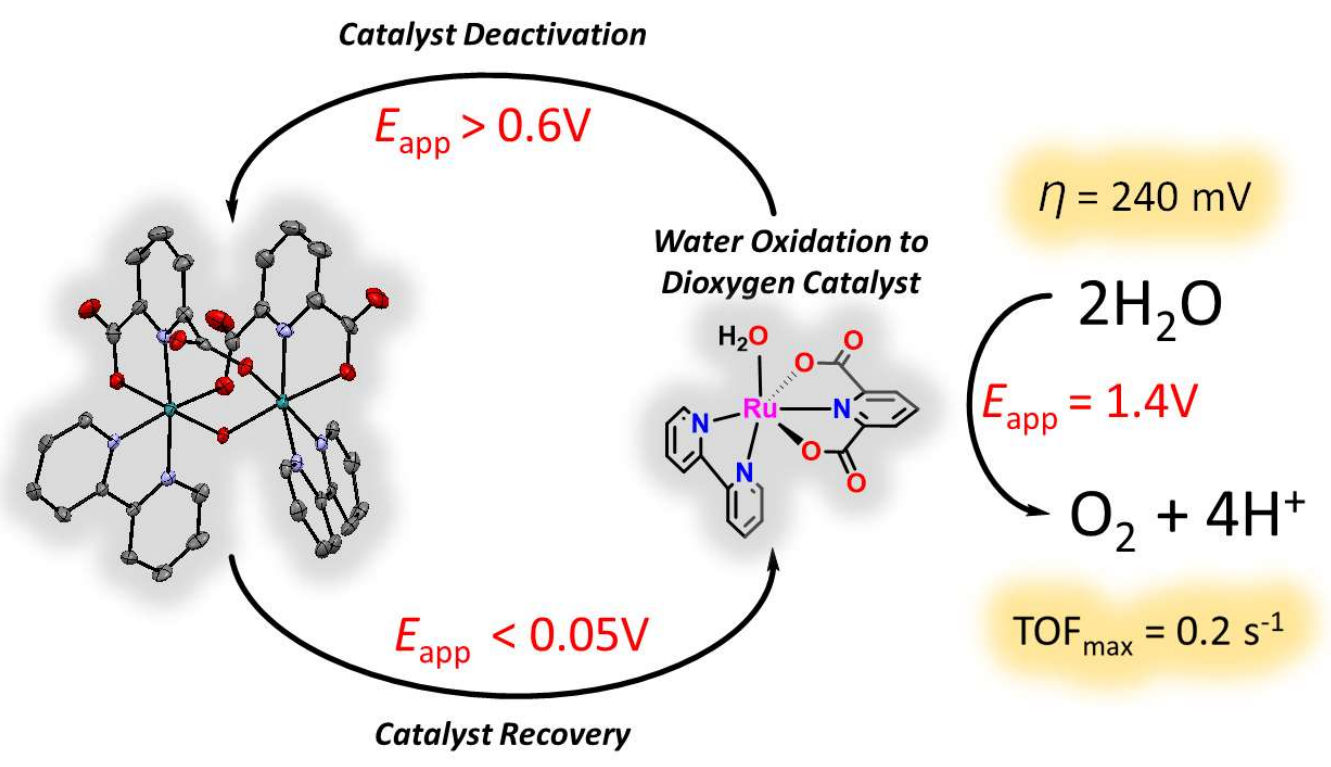

